Linköping University Medical Dissertation No. 1781

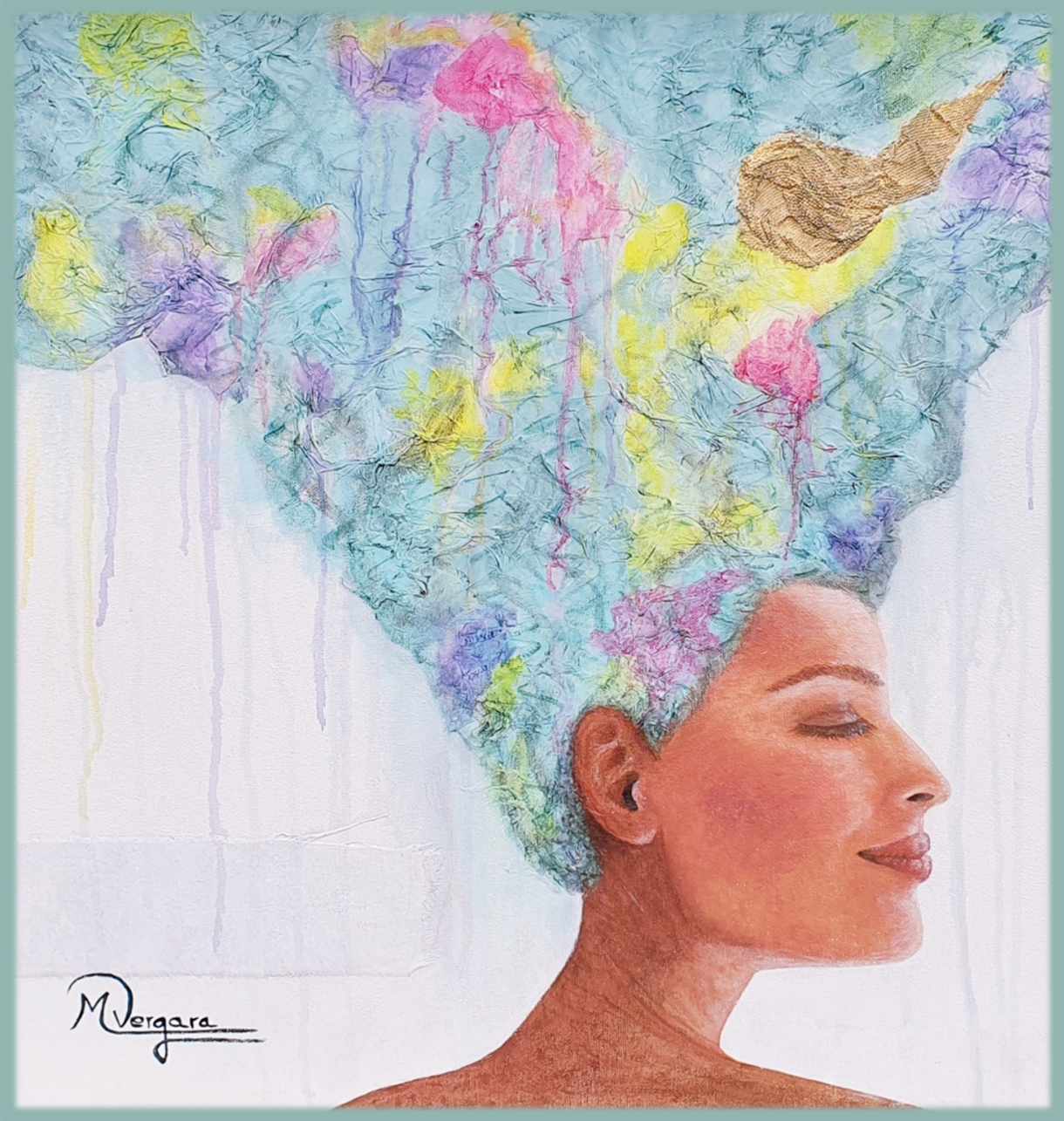

\title{
Impact of different interventions on cardiovascular risk factors
}

\author{
Marta Vergara
}

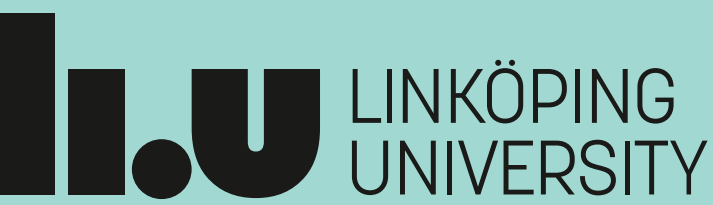





\title{
Impact of different interventions on cardiovascular risk factors
}

\author{
Marta Vergara
}

L.0.

Department of Health, Medicine and Caring Sciences

Linköping University, Sweden

Linköping 2021 
(oc) EY-No This work is licensed under a Creative Commons AttributionNonCommercial 4.0 International License.

https://creativecommons.org/licenses/by-nc/4.0/

(C) Marta Vergara, 2021

Cover: Marta Vergara, Breeze.

Published articles have been printed with the permission of the copyright holder.

Printed in Sweden by LiU-Tryck, Linköping, Sweden, 2021

ISBN 978-91-7929-655-1

ISSN 0345-0082 
"Who said melancholy is elegant?

Take off that mask of sadness,

there is always a reason to sing,

to praise the most holy mystery,

let's not be cowards,

let's run to tell anyone,

there is always someone we love and who loves us".

Gloria Fuertes

To Ainhoa, Inés and Alba. 


\section{TABLE OF CONTENTS}

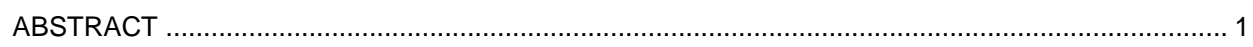

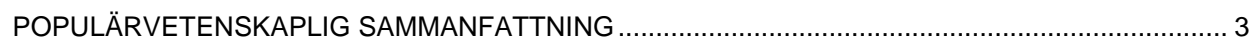

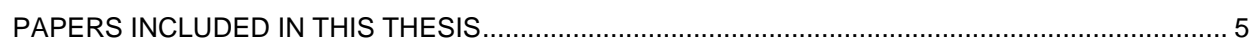

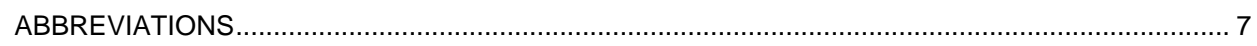

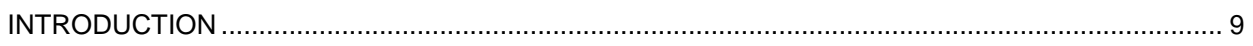

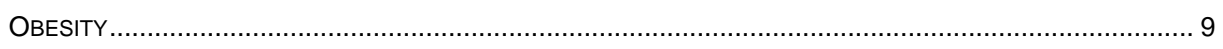

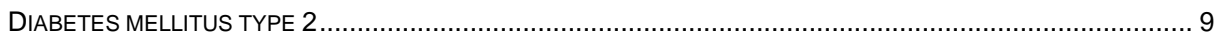

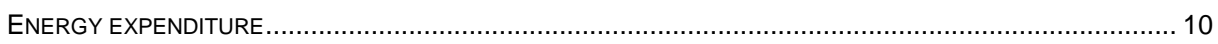

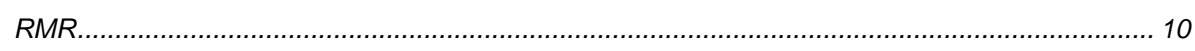

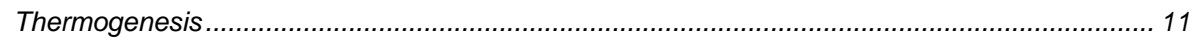

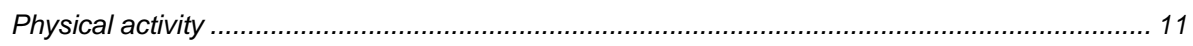

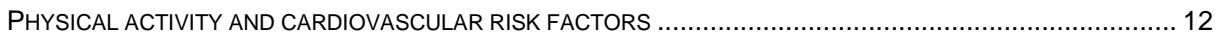

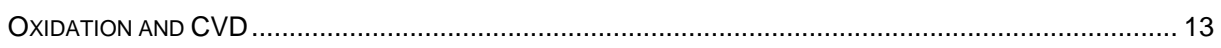

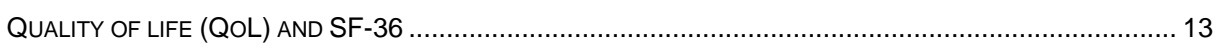

QoL

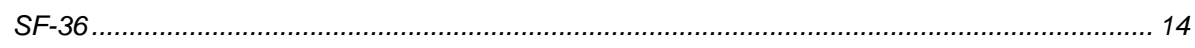

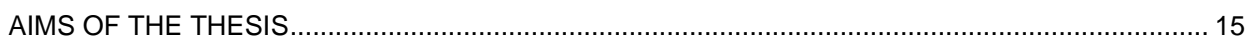

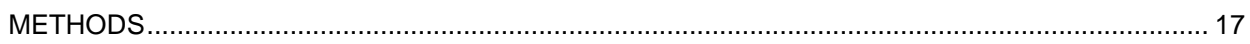

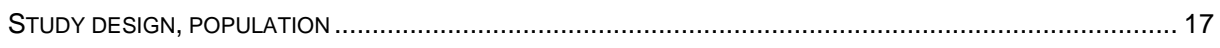

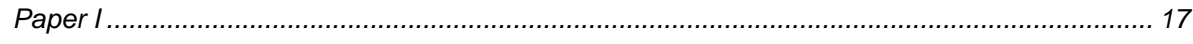

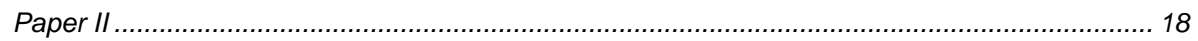




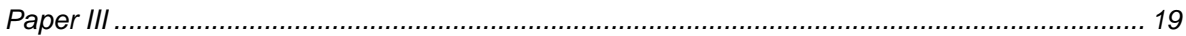

Paper IV

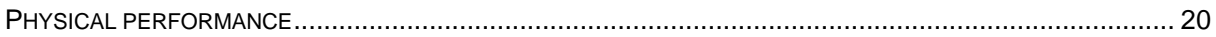

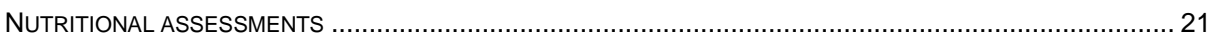

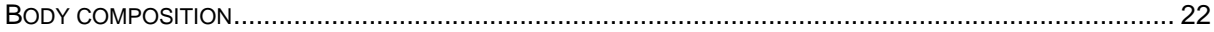

RMR

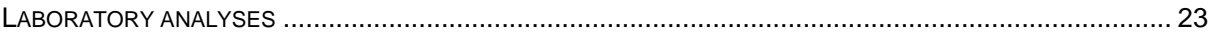

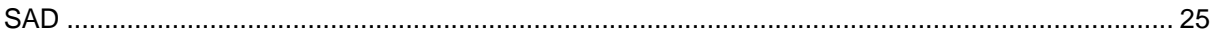

PWV

STRESS TEST

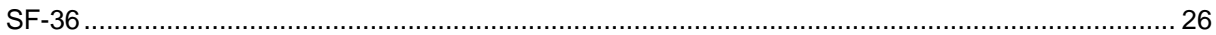

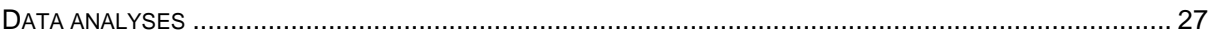

ETHICS

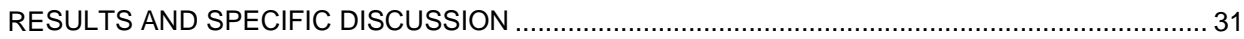

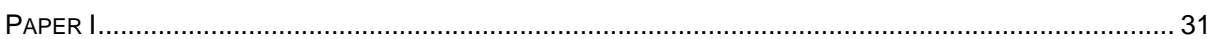

Body composition and intake of macronutrients..................................................................... 31

RMR

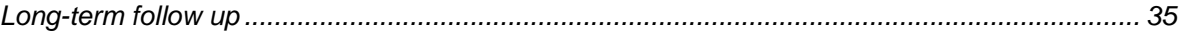

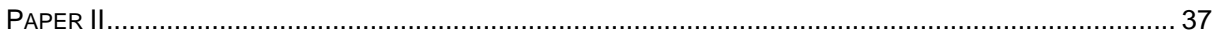

Results in mixed population: with and without blueberries................................................... 37

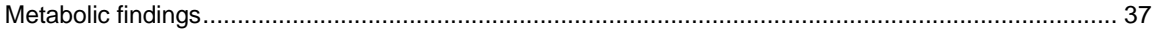

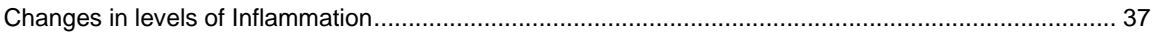

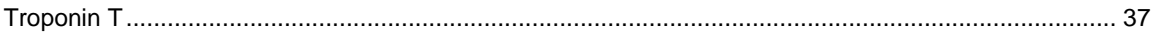

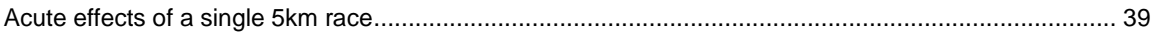

Effects of adding blueberries to the diet during the exercise period ........................................... 39

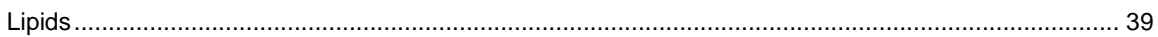

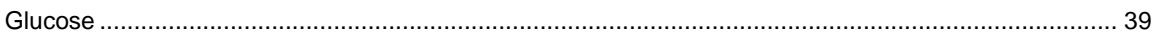

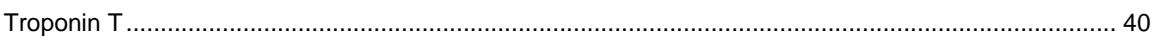

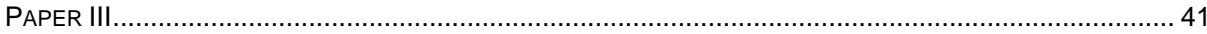

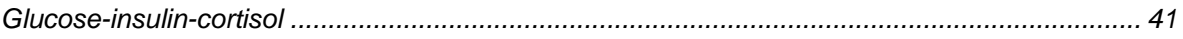




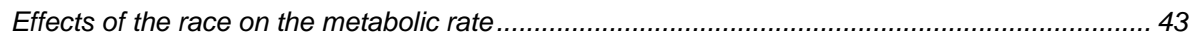

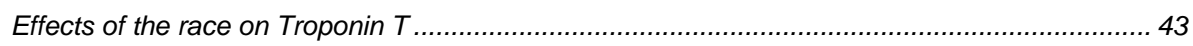

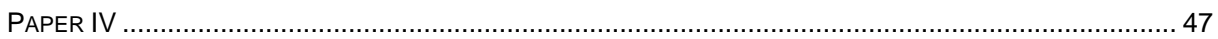

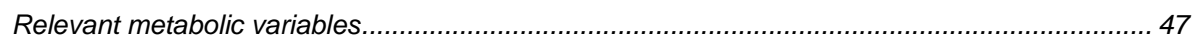

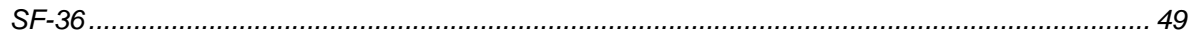

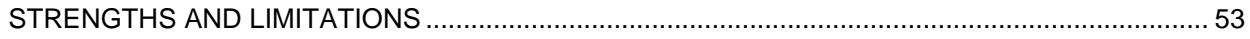

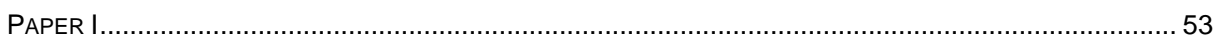

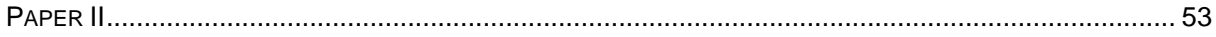

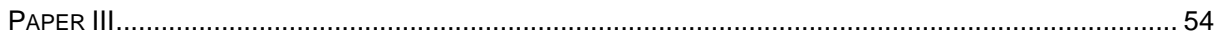

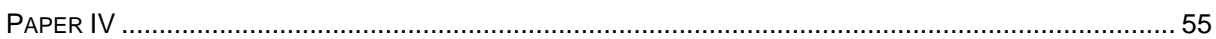

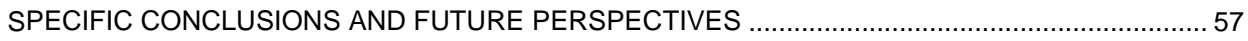

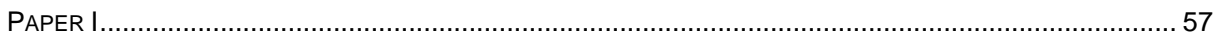

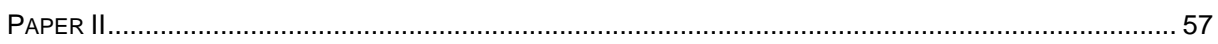

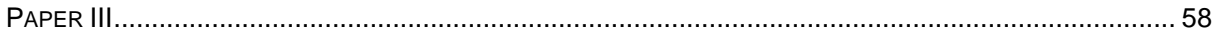

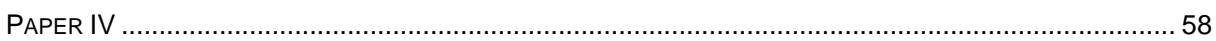

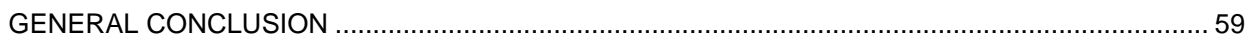

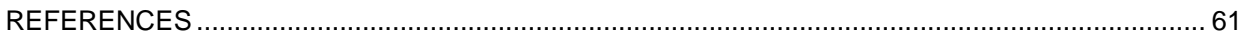

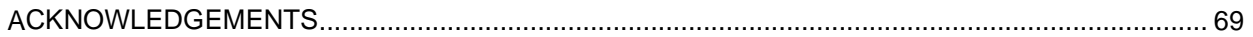




\section{ABSTRACT}

Obesity and related complications such as diabetes mellitus type 2 (T2DM) and cardiovascular events, are a growing major health problem worldwide. Achieving a negative energy balance by increasing physical activity in combination with reduced caloric intake, is the most common approach in weight reduction strategies, something that is difficult to maintain in the long term. Other possible strategy to increase energy expenditure could be enhancing resting metabolic rate (RMR) by increasing energy consumption in muscle tissue. Regular exercise is often recommended as part of the treatment and prevention of cardiovascular disease (CVD) and it is expected to ameliorate risk factors associated with the metabolic syndrome, such as glucose and insulin metabolism, lipid profile and blood pressure. However, extreme exercise performance seems to have potential unbeneficial effects on inflammation, oxidation, and cardiac health. We intended to study the impact of a more common way of exercise in different cardiovascular risk factors and how natural antioxidants, protein supplementation or hypercaloric diet could influence the results.

In patients with already established T2DM, it is important to find new and easy to manage markers for CVD, as it is the main cause of morbidity and mortality in this patient group. Even if quality of life (QoL) is strongly related to CVD in patients with T2DM, it is still not incorporated in routinary clinical assessments.

Paper I: Resistance training (RT) performed by healthy men for three months, increased lean body-mass and RMR. The increase of RMR was dependent on both an increase in muscle mass and a higher RMR per $\mathrm{kg}$ of muscle tissue. Even if it was equally efficient to combine training with whey protein supplementation or with increased energy intake, hyperalimentation with an extra intake of a fast-food resulted in an impaired cardiovascular profile, with reduced insulin sensitivity and higher ApoB levels. Thus, regularly performed RT could be helpful in the treatment of obesity by increasing RMR. 
Paper II: Regularly running $5 \mathrm{~km}$ for 4 weeks resulted in a positive outcome, leading to lower insulin and triglyceride levels, higher HDL cholesterol, and a tendency to lower inflammation when compared with a period of minimal physical activity. However, Troponin$\mathrm{T}$, marker of myocardial injury, was detectable after a $5 \mathrm{~km}$ race at maximal speed in almost half of the races. Consuming blueberries showed a cardioprotective effect, blunting troponinT release and improving the lipid profile. Less positive was the increase of fasting glucose in consumers of blueberries, which could be an indirect effect of concomitant diet.

Paper III: Running $5 \mathrm{~km}$ at maximal speed may not be as advantageous for cardiovascular health as expected, at least when looking at the acute effects of a single race in healthy young individuals. A relative short race seemed to reduce insulin sensitivity and despite increased insulin levels, glucose was higher directly after the race compared with a resting day. Indeed, we found elevated cortisol and Troponin-T levels after the races, which suggests that running a distance that is common among recreational runners, may not be fully advantageous for cardiovascular health when performed in a strenuous way.

Paper IV: We investigated if selected questions regarding the domains "general mental health and well-being" and "vitality", from QoL measurement instrument SF-36, could predict cardiovascular events and death in patients with T2DM in primary care. These two questions: "During the last 4 weeks, did you feel full of pep?" and "During the last 4 weeks, did you have a lot of energy?" were shown to be markers for major adverse cardiovascular events (MACE) independently of traditional vascular risk factors as well as arterial stiffness. 


\section{POPULÄRVETENSKAPLIG SAMMANFATTNING}

Övervikt har blivit en världsepidemi som stiger i ökande takt. Nästan var tredje människa i världen är fet. Att vara fet innebär en ökad risk att drabbas av ohälsa som kan leda till allvarliga komplikationer och i visa fall döden. Övervikt kan i längden medföra olika sjukdomar som diabetes typ 2 (T2DM), som innebär att kroppen svarar dåligt på egen produktion av insulin och sockerhalten i blodet blir för högt. Det kan ge uppkomst till andra tillstånd som höga blodfetter, högt blodtryck, m.m. Dessa kan i sin tur resultera i kärlsjukdom och efterföljande komplikationer som hjärtinfarkt eller stroke. Andra organ som lever, njurar, ögon, etc. kan också skadas av diabetes. Övervikt går att förebygga, och de vanligaste strategierna för att uppnå viktnedgång inkluderar en ökad energiförbrukning och minskat energiintag, vilket är svårt att behålla i längden. Ett alternativt sätt för att uppnå viktnedgång kunde vara att öka den basala ämnesomsättningen, d.v.s. energin som används för att upprätthålla kroppens grundläggande funktioner, genom att öka energiförbrukningen i musklerna. Att träna regelbundet rekommenderas ofta för att både gå ner i vikt och för att minska risken för att utveckla hjärtkärlsjukdomar, och förväntas förbättra klassiska riskmarkörer som höga blodfetter eller högt blodtryck. Däremot, kan det bli skadligt när träningen utförs i extrema former. Vi har studerat vanliga motionsformer och dess inverkan på kända markörer för hjärtkärlsjukdomar och hur de kan påverkas av olika strategier som intaget av en extra måltid av snabbmat, proteinpulvertillskott eller förtäring av blåbär innehållande naturella antioxidanter och vitaminer. Det är viktigt att identifiera vilka diabetespatienter som löper högre risk att utveckla en allvarlig hjärtkärlkomplikation, och även om vi vet att livskvalitet har en tydlig koppling till patienter med T2DM, så är det ännu ej rutin att mäta detta vid uppföljning av dessa patienter.

Denna avhandling består av fyra studier som syftar bl.a. till att undersöka hur olika strategier kan påverka klassiska riskfaktorer för hjärt-kärlsjukdom. 
Delarbete I: Friska men som styrketränade under tre månader, ökade muskelmassan och ämnesomsättningen oberoende av extra intaget av proteinpulver eller snabbmat. Däremot, fick deltagarna som åt den extra kaloririka måltiden, sämre insulinkänslighet och sämre blodfetter, vilket inte är så hälsosamt. Att genomföra regelbunden styrketräning kan hjälpa mot övervikt genom att öka ämnesomsättningen och förbruka mer energi även i vila.

Delarbete II: Friska personer som fick springa $5 \mathrm{~km}$ regelbundet under en månad hade mer gynnsamma blodfetter och insulinnivå, och en tendens till lägre inflammation jämfört med inaktivitet. Däremot, hittades i blodet mätbara nivåer av Troponin-T, som är en markör av hjärtmuskelskada, i nästan hälften av alla lopp. Deltagarna som fick äta blåbär de dagar de sprang, fick högre sockernivåer, vilket tros bero på att det var vanligt att blanda bären med annan föda innehållande socker. Däremot, verkade blåbären vara skyddande för hjärtat och kärlen, eftersom dessa individer hade lägre nivåer av Troponin-T och finare blodfetter.

Delarbete III: Vi mätte effekter av ett enskilt lopp på 5 km i högsta hastighet i en grupp friska och unga personer och jämförde resultatet med en dag av inaktivitet. Trots det relativt korta avståndet, fick dessa individer en försämrad insulin-sockeromsättning, Troponin-T läckage och högre nivåer av kortisol (som är ett stresshormon) i direkt anslutning till loppet. Våra resultat antyder att ett lopp på $5 \mathrm{~km}$ i maximal hastighet kanske inte är fullständigt hälsosamt sett från ett hjärt-kärlperspektiv.

Delarbete IV: 752 patienter med T2DM följs upp sedan 2008 för att observera vilka som får allvarlig hjärt-kärlsjukdom som leder till sjukhusinläggning eller död. Vi studerade om specifika frågor tagna ur ett känt frågeformulär för mätning av livskvalitet, kunde användas som riskmarkörer. De här följande två frågor visade sig kunna förutsäga risken att utveckla allvarliga hjärt-kärlkomplikationer oberoende av andra riskmarkörer:

"Hur stor del av tiden under de senaste fyra veckorna har Du känt Dig riktigt pigg och stark?" och ” Hur stor del av tiden under de senaste fyra veckorna har Du varit full av energi?". Vi föreslår att dessa frågor skulle kunna integreras i vanliga rutiner vid uppföljning av patienter med T2DM för att kunna identifiera de som har högre risk att utveckla den typen av komplikationer i god tid. 


\section{PAPERS INCLUDED IN THIS THESIS}

\section{Paper I}

A randomized trial of protein supplementation compared with extra fast food on the effects of resistance training to increase metabolism

David Hambre, Marta Vergara, Yvonne Lood, Margareta Bachrach-Lindström, Torbjörn Lindström \& Fredrik H. Nystrom (2012) Scandinavian Journal of Clinical and Laboratory Investigation, 72:6, 471-478, DOI: 10.3109/00365513.2012.698021

Published online: 30 Aug 2012

\section{Paper II}

Effects of exercise with or without blueberries in the diet on cardio-metabolic risk factors: An exploratory pilot study in healthy subjects

Sofia Nyberg, Edvard Gerring, Solveig Gjellan, Marta Vergara, Torbjörn Lindström \& Fredrik H Nystrom (2013) Upsala Journal of Medical Sciences, 118:4, 247-255, DOI: $10.3109 / 03009734.2013 .825348$

Published online: 27 Aug 2013

\section{Paper III}

A randomized crossover study of the acute effects of running $5 \mathrm{~km}$ on glucose, insulin, metabolic rate, cortisol, and Troponin $\mathrm{T}$

Keselman B*, Vergara M*, Nyberg S, Nystrom FH (2017). PLOS ONE 12(6): e0179401. https://doi.org/10.1371/journal.pone.0179401

Published online: 16 Jun 20017

* These authors contributed equally to this work

\section{Paper IV}

Sense of vitality predicts risk for cardiovascular events and death in type 2 diabetes independently of traditional risk factors and arterial stiffness

Marta Vergara, Carl Johan Östgren, Fredrik Nyström, Hanna Israelsson Larsen. Department of Health, Medicine and Caring Sciences, Faculty of Medicine and Health Sciences, Linköping University, SE 581 85, Linköping, Sweden.

Submitted

Published papers have been reprinted with the permission of the copyright holder. 


\section{ABBREVIATIONS}

\begin{tabular}{|c|c|}
\hline BMR & Basal metabolic rate \\
\hline RMR & Resting metabolic rate \\
\hline T2DM & Diabetes mellitus type 2 \\
\hline CVD & Cardiovascular disease \\
\hline BAT & Brown adipose tissue \\
\hline WAT & White adipose tissue \\
\hline RT & Resistance training \\
\hline ET & Endurance training \\
\hline HRQoL & Health-related quality of life \\
\hline QoL & Quality of life \\
\hline SAD & Sagittal abdominal diameter \\
\hline PWV & Pulse wave velocity \\
\hline MACE & Major adverse cardiovascular event \\
\hline ECG & Electrocardiogram \\
\hline WC & Waist circumference \\
\hline DEXA & Dual energy x-ray absorptiometry \\
\hline CARDIPP & Cardiovascular risk factors in patients with diabetes \\
\hline HOMA & Homeostasis model assessment \\
\hline QUICKI & Quantitative insulin sensitivity check index \\
\hline SBP & Systolic blood pressure \\
\hline AMP & Adenosinmonophosphate \\
\hline $\mathrm{GH}$ & Growth hormone \\
\hline IGF-1 & Insulin-like growth factor type 1 \\
\hline HPA & Hypothalamic-pituitary-adrenal axis \\
\hline IMT & Intima-media thickness \\
\hline
\end{tabular}




\section{INTRODUCTION}

\section{Obesity}

Obesity has become a chronic metabolic disease and a major health problem that is increasing worldwide and affecting more than a billion humans ${ }^{1-3}$ as a consequence of lifestyle changes that include sedentarism and less healthy diets. People suffering from obesity have an increased risk of developing dyslipidemia, insulin resistance, metabolic syndrome, cardiovascular disease (CVD), type 2 diabetes mellitus (T2DM), low-grade inflammation, a procoagulant state, hypertension, and cancer $^{4-9}$.

In healthy people in general, despite individual variations, body weight is related to energy balance ${ }^{10,11}$. A positive balance with higher energy intake than energy consumption results in weight gain. There are multiple approaches to achieve weigh reduction, but most of the strategies attempt to accomplish a negative energy balance by increasing physical activity and reducing energy intake at same time, which is hard to maintain over a long period of time, requiring strong motivation and often resulting in unsuccessful attempts ${ }^{12,13}$. New, easy-tomanage strategies to reduce weight are needed.

\section{Diabetes mellitus type 2}

T2DM is a chronic illness the prevalence of which increases and parallels that of obesity, and it is estimated that 439 million people will have T2DM by the year $2030^{14}$. It is characterized by insulin resistance and hyperglycemia ensues when the pancreatic beta-cells no longer manages to withhold the high demand of insulin production ${ }^{15}$. In a pre-stadium of the condition, the patients have an increased resistance to insulin that is usually associated with the metabolic syndrome. Even if it is possible to diagnose at this point, it is still often missed, losing the opportunity to treat this condition in good time, and in some cases, leading to microvascular complications already present at the time of diagnosis ${ }^{16}$. 
Patients with T2DM run a high risk for developing microvascular disease. Diabetic retinopathy is the most common microvascular complication and cause of blindness, followed by nephropathy and diabetic neuropathy. Macrovascular complications are even stronger linked with T2DM, and they manifest as $\mathrm{CVD}^{17}$, which is the main cause of premature death in patients $\mathrm{T} 2 \mathrm{DM}{ }^{18,19}$.

Lifestyle and diet modifications are still the most important interventions to prevent T2DM ${ }^{20-}$ 23. This should be the main target in the management of T2DM as it is almost not possible to cure this condition despite novel drugs and promising investigations ${ }^{24}$, with the exception of bariatric surgery in obese patients with $\mathrm{T}_{2} \mathrm{DM}^{25,26}$.

\section{Energy expenditure}

Energy expenditure consists of three main components: resting metabolic rate (RMR), thermogenesis and physical activity ${ }^{27}$.

\section{$R M R$}

RMR is the minimal quantity of energy required for an organism to be alive $\mathrm{e}^{28}$ and it is estimated by measuring the heat production during conditions of rest, fasting and thermal neutrality. It is the largest component of daily energy consumption and is believed to be genetically determined and highly variable. It is known that obese individuals may have high RMR that decreases during weigh loss as an energy saving adaptation ${ }^{29,30}$, making it difficult to continue losing weight.

Modifying RMR could be an additional strategy in the weight reduction challenge. A high metabolism may protect against obesity by consuming a lot of energy even at rest. Levels of thyroid hormones ${ }^{31}$ and the activity in the sympathetic nervous system ${ }^{32}$ regulate the RMR, but an important target when trying to increase metabolism should be lean body mass, as RMR is strongly related to body composition and the amount of muscle mass ${ }^{11,33,34}$.

In the previously conducted "Fast Food Study"35 young healthy individuals who were randomized to diminish physical activity and double their calorie intake mainly through fast food or protein supplements, gained muscle mass, and their metabolism increased on average 
by $10 \%$. This could mean that increased muscle mass facilitates energy expenditure and hence could help to lose weight.

\section{Thermogenesis}

Thermogenesis is the production of heat by physiological processes, and it is basically compounded by the thermic effect of live supporting processes such as breathing, digesting, etc., and additional thermogenesis, which includes:

- thermal component: shivering thermogenesis in muscle and non-shivering in brown adipose tissue (BAT).

- energy component: diet-induced thermogenesis in BAT and exercise-induced in muscle ${ }^{36}$.

There are basically two types of adipose tissue, white adipose tissue (WAT) and brown adipose tissue. BAT is involved in heat production when there is a need for extra heat, and when induced by certain components in food, mostly by diets low in protein ${ }^{37}$, while WAT releases hormones and cytokines involved in metabolism and acts as energy storage and insulation ${ }^{38-40}$. It seems feasible to modify the amount and activity of BAT by exposure to cold $^{41}$. Nyström FH et al., a co-author of the papers included in this thesis, has shown in an earlier trial that it is possible to increase BAT volume and the metabolic rate by repeated exposure to cold in humans ${ }^{42}$. In accordance with my own unpublished data of using a cold vest, increasing thermogenesis by enhancing BAT could be a convenient way to increase energy expenditure and hence to reduce body weight, as well as a potential path to improve lipid prolife ${ }^{43,44}$ and reduce glucose levels ${ }^{45}$, since these are the main substrates for the heat production in $\mathrm{BAT}^{37,46}$.

\section{Physical activity}

Physical activity is another component of energy expenditure. Physical activity is usually recommended in combination with reduced calory intake to achieve a negative energy balance and reduce weight. Both resistance training (RT) and endurance training (ET) reduce total fat weight and may prevent the expected decrease in RMR that usually follows a period of negative energy balance and weight $\operatorname{loss}^{47}$, by maintaining or increasing fat-free weight and increasing the metabolic rate for several hours after the ceasing of exercise $\mathrm{e}^{48,49}$. 
The individual variation in RMR is substantially determined by the amount of lean body mass and it is well explored that RMR increases secondary to RT, at least in men ${ }^{50-53}$.

Hypothetically, another way to increase muscle mass, and as a secondary result increase energy expenditure, could be to stimulate insulin release by diet, which could possibly potentiate the anabolic effect of insulin. It is showed that insulin and IGF-1 have an anabolic effect in muscle protein by inhibiting proteolysis, respectively stimulating protein synthesis, at least under a sufficient availability of aminoacids ${ }^{54}$.

\section{Physical activity and cardiovascular risk factors}

Increasing physical activity is not only recommended in the context of weight loss strategies, as described above. It is also common to integrate exercise in the treatment of many components of the metabolic syndrome that are considered risk factors for CVD. Regularly performed exercise with a frequency of several times per week may help to improve lipid status, reduce blood pressure, increase insulin sensitivity, and decrease glucose levels at least in patients with lower insulin sensitivity, such as patients with $\mathrm{T}_{2} \mathrm{DM}^{55-58}$.

It is a known phenomenon that healthy subjects who perform strenuous physical exercises such as triathlons, marathons, and other elite athletes, may suffer negative effects as a consequence of this extreme exercise form, showing an increase in inflammation markers ${ }^{59-}$ 63 . This seems to be more evident in individuals that are not sufficiently fit, as inflammation decreases when exercise is performed regularly and for a minimal period of time, suggesting that it is possible to suppress the inflammatory response through intensive and regular training ${ }^{64}$.

Other potentially unfavorable effects of strenuous exercise from a cardiovascular point of view are the release of troponin $\mathrm{T}^{59,65,66}$, a specific marker for cardiac myocyte damage ${ }^{67}$, and the acute increase in stress hormones like cortisol, after high-intensity exercise ${ }^{68}$. Cortisol excess has hyperglycemic and insulin resistance effects, inducing hyperinsulinemia. It may also result in hypertension, abdominal obesity, and dyslipidemia ${ }^{69}$. At the same time, exercise increases insulin sensitivity and insulin-independent glucose upptake $\mathrm{e}^{70,71}$. 


\section{Oxidation and CVD}

Free radicals and oxidation may cause damage to DNA, lipids, proteins, and other biomolecules. Endogenous antioxidants are not sufficient to avoid this damage and dietrelated antioxidants are an important complement ${ }^{72}$. However, it has been difficult to prove the antioxidant effect of certain substances that seem to work experimentally ${ }^{73}$, but when used in humans, may be harmful and even increase mortality ${ }^{74}$. This does not prevent people from consuming antioxidants in the form of supplements despite unsure data ${ }^{75,76}$.

However, the ingestion of blueberries with their high concentration of polyphenols, resveratrol and other substances such as vitamin $C^{77}$, has shown cardioprotective effects ${ }^{78}$.

\section{Quality of life (QoL) and SF-36}

\section{QoL}

QoL is defined by WHO as an individual's perception of their position in life in the context of the culture and value systems in which they live and in relation to their goals, expectations, standards and concerns ${ }^{79}$. The concept of QoL has also been defined as the individual's measurement of the 'goodness' of multiple aspects of their life. These evaluations include one's emotional reactions to life occurrences, disposition, sense of life fulfilment and satisfaction, and satisfaction with work and personal relationships ${ }^{80}$.

The terms health, health-related quality of life (HRQoL) and QoL are commonly used interchangeably in literature, and this may lead to confusion. Multiple attempts have been made to find definitions that distinguish between these terms, and although it is easier to differentiate Health and QoL, drawing a distinction between HRQoL and both health and QoL is still problematic ${ }^{81}$. The term QoL is used consistently in this thesis and the related published paper.

QoL has, in recent decades, been more present in research when exploring risk factors for CVD, in addition to traditional risk factors such as high blood pressure, hyperlipidemia, abdominal fat, etc. A relationship between psychosocial risk factors (e.g., depression and stress) and CVD is well established in the general population ${ }^{82,83}$ and an independent 
prognostic value of QoL regarding all-cause mortality has also been established, even after adjustment for important demographic, socioeconomic, and clinical risk factors ${ }^{84}$.

It has been suggested that T2DM patients with poor glycemic control have lower QoL scores $^{85}$, and that poor QoL scores show strong adjusted associations with the incidence of CVD in a population with no CVD history at baseline ${ }^{86}$. In addition, higher QoL in patients with T2DM may be associated with a lower risk of vascular events and fewer diabetes complications independently of other established risk factors for $\mathrm{CVD}^{87}$. In T2DM patients, there are several studies that suggest an impact of cardiovascular events on QoL ${ }^{88}$, but QoL as an independent predictor of CVD in T2DM patients has not been thoroughly investigated.

\section{SF-36}

The SF-36 questionnaire is the most commonly used measurement instrument for QoL $^{89}$ - it is accessible, well validated ${ }^{90}$ for numerous professions, and has good reliability ${ }^{91}$ even when using the Swedish version ${ }^{92-94}$, which was the relevant questionnaire used in our investigation.

It was constructed to be used in clinical practice and research, health policy evaluations, and general population surveys ${ }^{95}$. Over 5000 published studies have been carried out using the SF36, showing its abilities as a global QoL measurement instrument.

Although strong associations between QoL and morbidity and mortality have been reported, QoL is still not established as a risk factor for CVD, and thus not incorporated in clinical routines. The reason is probably difficulties in measuring psychosocial health and QoL in a standardized, practical manner, in clinical practice. The SF-36 questionnaire takes about 10 minutes to complete, and although patients can fill it in at home, it still takes time to check the answers with the patient and analyze them, and it is difficult to assess the clinical significance of the results. We decided to use a selected part of the SF-36 questionnaire to simplify the management of this type of questionnaire. 


\section{AIMS OF THE THESIS}

The overall aim of this thesis was to study the relationship between different metabolic markers and the risk of developing CVD.

The specific aims were:

- To prospectively evaluate the effects of resistance training combined with increased energy intake or protein supplementation on RMR, muscle mass, and cardiovascular risk factors. (Paper I).

- To examine the effects of regular exercise with or without blueberries, containing natural antioxidants, on cardio-metabolic risk factors. (Paper II).

- To study the impact of running $5 \mathrm{~km}$, at maximal speed, on the normal variations of metabolic variables related to glucose, insulin, insulin sensitivity, cortisol, glucagon, RMR and troponin T. (Paper III).

- To investigate whether there are independent associations between QoL measured as separate items from the SF-36 questionnaire and cardiovascular events and mortality in patients with T2DM. (Paper IV). 


\section{METHODS}

\section{Study design, population}

\section{Paper I}

This is a randomized prospective pilot study in which we recruited 24 normal weight males aged 19-32 years by local advertisement. They were healthy and not body builders. The subjects were randomly assigned either to 3 months of resistance training in combination with an extra fast-food-based meal/day, or the same kind of resistance training in combination with a whey protein supplement. We included monitoring at 12 months after baseline, during which participants did not get any instructions about diet or training. 19 of the participants were available for the long-term follow up.

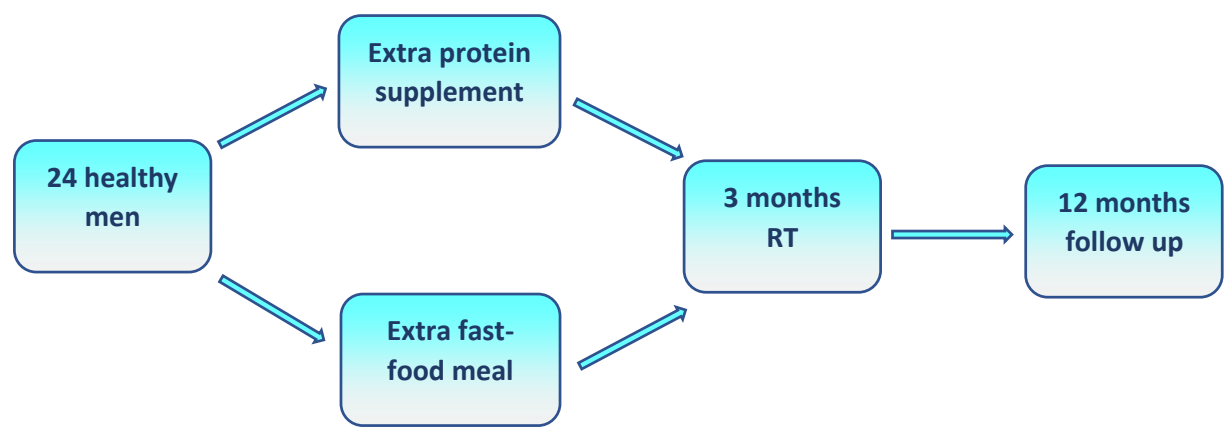

Fig. 1 Study design Paper I 
RMR, blood samples and urine testosterone were taken in the morning at fasting state. The strength was measured by recording the torque of the quadriceps and hamstring muscles. (Table 1)

Table 1. Time-point for the measurements in the study. 12-month measurement only applicable to the subjects who stayed in long-term follow up. Muscle diameter: upper arm, thigh, waist, and gluteal region.

\begin{tabular}{|c|c|c|c|c|}
\hline & BASELINE & 1 MONTH & 3 MONTHS & 12 MONTHS \\
\hline STRENGTH & $\mathrm{V}$ & & $\mathrm{V}$ & $\mathrm{V}$ \\
\hline RMR & $\mathrm{V}$ & V & $\sqrt{ }$ & V \\
\hline DEXA & V & & $\sqrt{ }$ & V \\
\hline U-TESTOSTERONE & V & & $\sqrt{ }$ & \\
\hline BLOOD SAMPLES & V & V & $\sqrt{ }$ & V \\
\hline 7-DAY DIET DIARY & V & & $\sqrt{ }$ & \\
\hline SAD & V & $\sqrt{ }$ & v & v \\
\hline BLOOD PRESSURE & V & V & v & $\sqrt{ }$ \\
\hline QUESTIONAIRES & v & V & $\sqrt{ }$ & V \\
\hline MUSCLE DIAMETER & V & $\mathrm{V}$ & V & v \\
\hline
\end{tabular}

RMR: resting metabolic rate, DEXA: Dual energy x-ray Absorptiometry, SAD: sagittal abdominal diameter.

\section{Paper II}

We recruited 32 healthy volunteers, 15 men and 17 women, with some earlier experience of running. The design is a randomized crossover trial with 4 weeks of exercise by running/jogging $5 \mathrm{~km}$ five times/week and 4 weeks of minimal physical activity, with a washout period of 4 weeks in which they returned to their regular exercise habits. The participants were randomized to start with the exercise period or with the period of minimal physical activity and to consume $150 \mathrm{~g}$ of frozen blueberries the day they exercised, or to keep their eating habits unchanged. At the beginning and end of each trial period, the participants ran $5 \mathrm{~km}$ in the fastest possible time in the evening (at 6 p.m.). (Fig. 2) 


\section{Time}

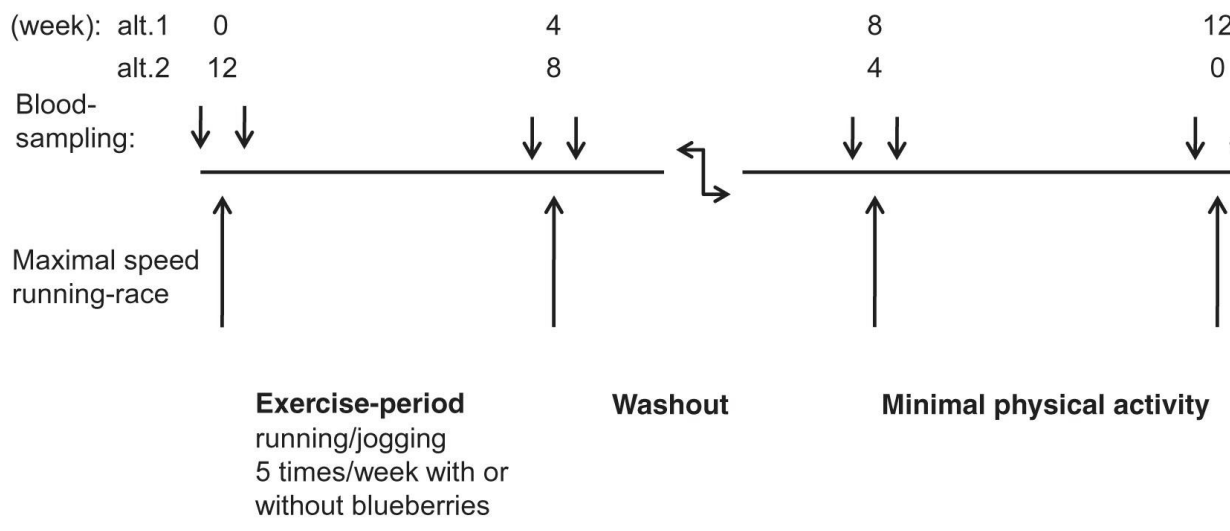

Fig. 2. Study design Paper II. The figure shows a schematic presentation of the study design for a participant randomized to start with the exercise period when reading the figure from left to right.

Each participant who completed the whole trial ran a total of 4 running-races at maximal speed, and venous blood was correspondingly drawn 8 times in the fasting state; thus, he or she had one period of exercise, a washout period, and also a period of minimal physical activity in this crossover trial. Blood samples for the analysis of cardio-metabolic risk markers were taken after an overnight fast on the morning of the maximal speed running-race, and the corresponding morning after, except for troponin-T which was analyzed only from samples after the races.

The participants made a stress test at the end of each trial period, measuring salivary cortisol and blood pressure. The determination of body fat was done with BodPod, also at the end of both main periods.

\section{Paper III}

In this randomized crossover study, via local advertising we recruited 19 healthy and normal weight individuals, women and men, with previous experience of running. The participants were studied on two separate occasions with at least two days apart, being randomized to 5 $\mathrm{km}$ outdoor running at individual maximal speed or a resting period of 45 minutes. Blood samples were collected 6 times during the study day, including before and after the race or the rest period, except for Troponin-T which was also taken 24 hours after the race. Salivary 
cortisol was taken at the same time as the blood samples, plus at bedtime and the morning after the study day. Electrocardiogram (ECG), was recorded after the race and the resting period, and RMR was measured with Deltatrac 4 times per study day, at $08.00 \mathrm{~h}, 10.00 \mathrm{~h}$, $14.00 \mathrm{~h}$ and $17.30 \mathrm{~h}$. A standardized breakfast and lunch were provided during the 2 study days.

\section{Paper IV}

This study is part of the Cardiovascular Risk factors in Patients with Diabetes (CARDIPP) study ${ }^{96}$. CARDIPP is an observational prospective cohort study in primary care that recruited 761 patients between the years 2005 to 2008 , with an ongoing follow up. The patients were recruited by trained nurses from 22 different primary health care centers that adhered to the same national guidelines for diabetes care. Patients with severe physical or mental disease with a short life expectancy were excluded.

After baseline measurements, including blood samples, questionnaires, Sagittal Abdominal Diameter (SAD) and Pulse Wave Velocity (PWV), the patients were followed up continuously for major adverse cardiovascular event (MACE) via the Swedish National Inpatient Register, which comprises data on health care episodes in all inpatient specialist care, and the Swedish Cause of Death Register, which comprises data on all deaths of people registered in Sweden.

In this study, MACE was defined as the first non-fatal or fatal event of hospitalization for acute myocardial infarction, stroke or cardiovascular mortality, the same approach as in previous studies of the CARDIPP population.

\section{Physical performance}

\section{Paper I}

All participants attended a local gym, getting instructions for exercise with RT for at least 1 hour, 3 times a week at maximal muscle strength, doing 3-5 training sets with 8-10 repetitions in each one. No aerobic exercises should be done except when warming up. A gym 
instructor was available for coaching during the whole study period. The training schedule was recorded by the participants in diaries.

The torque of the quadriceps and hamstring muscles was recorded with a Biodex machine (Biodex Medical Systems Inc., Ronkonkoma, NY) after 5 minutes of warm-up on a bicycle ergometer. Three repetitions of maximal isokinetic $60 \%$ sec knee extension and flexion were documented using the dominant leg. The measurements were performed at baseline, within 1 week after the study period of 3 months and at the long-term follow up after 12 months when relevant.

\section{Paper II}

All the participants had some experience in running, but none were professional or elite runners. During the running period the participants ran $5 \mathrm{~km}$ at their own pace, 5 times a week for 4 weeks. They could run indoors or outdoors during this period, but the races that they did at maximal speed at the beginning and end of each study period were performed all on the same running track and outdoors when possible. Due to cold temperatures and snow, 13 subjects did the last running-race indoors or on a treadmill for safety reasons. During the period of minimal physical activity, they were instructed to move as little as possible, not even being allowed to walk to work or school, getting reimbursed tickets for public transport.

\section{Paper III}

The volunteers were, as in Paper II, used to running occasionally, but were not experienced runners. The two $5 \mathrm{~km}$ running-races in this study were performed outdoors after an overnight fast.

\section{Nutritional assessments}

\section{Paper I}

The fast-food based meal from well-known fast-food restaurants had a composition of about $1350 \mathrm{kcal}$ in total, $51 \mathrm{~g}$ of fat in total (saturated fat: $17 \mathrm{~g}$ ), $41 \mathrm{~g}$ protein and $182 \mathrm{~g}$ carbohydrates. It should be added as extra nutrient intake on top of the regular diet. In the protein group they were taking $33 \mathrm{gr}$ of $100 \%$ whey protein in addition to their normal diet. They were all provided with the same kind of whey protein powder. All the participants were given the directive of not losing weight because of the exercise, eating more if needed. They reported a 7-day diet diary before the start of the study and after 3 months of training, 
and the food composition of the meals reported in the diaries was analyzed using the Dietist XP program (Kost och Näringsdata, Bromma, Sweden).

\section{Paper II}

The blueberries consumed in our study were bought frozen on the same occasion from a regular local grocery store, in order to assure that there were no changes in nutrient composition during the study period. No particular instructions were given on how or when to consume the blueberries on the exercise days, in order to make potential findings easily incorporated in regular eating habits. The blueberries had a content of $40 \mathrm{kCal} / 100 \mathrm{~g}$ and had $0.5 \mathrm{~g}$ protein, $8 \mathrm{~g}$ carbohydrates, and $0.5 \mathrm{~g}$ fat per $100 \mathrm{~g}$ of the product.

\section{Paper III}

A standardized breakfast consisting of a ham sandwich, yoghurt and orange juice was given to the participants after the race or the corresponding prolonged rest period. The breakfast contained a total of $560 \mathrm{kCal}$ and was composed of $22 \mathrm{~g}$ protein, $15 \mathrm{~g}$ fat and $84 \mathrm{~g}$ of carbohydrates. Lunch consisted of a pre-packaged, frozen meal of pepper steak, potato gratin and red wine sauce containing a total of $468 \mathrm{kcal}$ based on $19.5 \mathrm{~g}$ from protein, $27.3 \mathrm{~g}$ from fat and $37 \mathrm{~g}$ from carbohydrates. Vegetarians and subjects with celiac disease were provided with equivalent meals of the same nutritional value. Water was offered as a drink with all the meals.

\section{Body composition}

\section{Paper I}

Body composition was established using Dual Energy X-ray Absorptiometry (DEXA: Lunar Prodigy, GE Health-care, Waukesha, Wisconsin, USA). DEXA is a well-validated method to measure fat mass and can provide accurate measurements of body composition with minimal radiation exposure ${ }^{97,98}$.

\section{Paper II}

The participants were subjected to determination of body fat content with BodPod (Life Measurement, Inc., Concord, CA, USA). The Bod Pod assesses \% fat by measuring body volume using air displacement plethysmography, which is a reliable, comfortable and easy-tomanage method for measuring body composition ${ }^{99}$. 


\section{RMR}

The measurements of the metabolic rate were done using indirect calorimetry using a Deltatrac Metabolic Monitor (Datex-Ohmeda Corporation, Helsinki, Finland for Paper III, and Delta Trac, Sensor-Medics, Yorba Linda, CA, USA for Paper I) according to the instructions of the manufacturer and as described earlier ${ }^{11,100}$. The technique is based on analysis of $\mathrm{CO}_{2}$ production and $\mathrm{O}_{2}$ consumption.

The measurements were performed at fasting state with the provided Deltatrac hood while the subjects were resting on a bed ${ }^{11}$ in a room at 21-22 degrees Celsius fully clothed, being instructed to lie still and relaxed during the test, and permitted to fall asleep.

The Deltatrac equipment was warmed up and stabilized before the beginning of each measurement session. The registration started when the subject's metabolism had individually stabilized, after approximately 3 to 8 minutes, taking a mean value of the last readings when they had stabilized.

\section{Laboratory analyses}

Standard laboratory investigations including high-sensitivity C-reactive protein (hs-CRP) (Paper II) were performed at the Department of Clinical Chemistry, Linköping University Hospital as part of their regular clinical routine analyses. The laboratory is accredited by SWEDAC (Swedish Board for Accreditation and Conformity Assessments).

- Urine-testosterone was determined by gas chromatography-mass spectrometry (7890A GC and 5975C MSD, Agilent Technologies, Santa Clara, California, USA) (Paper I).

- Serum-insulin was assayed using an immunoassay method (AutoDelfi a, Perkin Elmer, Link ö ping, Sweden) (Papers I, II) and using a Cobas e 602 analyzer, (Roche, Basel, Switzerland) (Paper III).

- Total cholesterol, HDL cholesterol and triglycerides were determined by colorimetric analyses (Siemens, Liederbach, Germany) (Papers I, II, IV)

- LDL cholesterol was calculated according to the Friedewald formula (total cholesterol _ HDLcholesterol_ 0.456 _ total triglyceride concentration) (Papers I, II, IV). 
- Levels of ApoB and ApoA1 were measured by immunoturbidimetric assays, Bayer Health Care and Siemens Diagnostic Medical Solutions (Tokyo, Japan) (Paper IV).

- Homeostasis model assessment (HOMA) index of insulin resistance was calculated as: fasting glucose x fasting insulin $/ 22.5^{101}$, while the Quantitative insulin sensitivity check index (QUICKI) was calculated as: 1/[log (fasting insulin) + log (fasting glucose)] according to Katz et al ${ }^{102}$ (Papers I, III).

- Capillary plasma glucose was measured with an Accu-Chek glucometer (Roche Diagnostics, Basel, Switzerland) (Paper III).

- HbAlc was analyzed according to the Swedish Mono-S HPLC standard which is approximately one percent unit lower than the Diabetes Control and Complications Trial (DCCT) standard (Paper IV).

- Troponin $\boldsymbol{T}$ was analyzed using an electrochemical luminescence method (Troponin T STAT Cardiac T, Cobas E411 equipment, Roche, Basel, Switzerland) (Papers II, III).

- Salivary cortisol. It was taken at different times as described in each paper. The participants were equipped with test tubes, cotton pads and written instructions for collection of cortisol in saliva. On the occasions that the samples were taken at home, the test tubes were preserved at the participants' homes, in the refrigerator, before being handed in to the study organizers. Details about the method for analysis of salivary cortisol have been described earlier ${ }^{103}$ and the method had a total CV of $14 \%$ when analyzed by Salimetrics Enzyme Immunoassay (Salimetrics LLC, Carlsbad, CA, USA) applied on a Nexgen Four analyzer (Adaltis, Milano, Italy) (Papers II, III).

- Serum cortisol was analyzed on Siemens Centaur XP equipment (Siemens, Munich, Germany) and had a total CV of $7.8 \%$ (Paper III).

- Plasma glucagon was measured by radioimmunoassay with a polyclonal antibody at the Department of Clinical Chemistry, Karolinska University Hospital, Stockholm, Sweden, and the total CV was $18 \%$ (Paper III). 


\section{SAD}

\section{Paper IV}

SAD was recorded with the patient in the supine position and with bent knees, with a standardized sliding beam caliper at the highest point of the abdomen. SAD has previously been suggested as a more important risk predictor for arterial stiffness over time, compared with waist circumference (WC), in middle aged men and women with T2DM ${ }^{104}$.

\section{PWV}

\section{Paper IV}

Determination of PWV was done at the Department of Physiology, Linköping University Hospital, Linköping and at the County Hospital Ryhov, Jönköping ${ }^{105,106}$. In brief, the aortic PWV was measured with applanation tonometry (SphygmoCor® system, model MM3, AtCor Medical, Sydney, Australia) over the carotid and femoral arteries. The aortic pulse wave transit times were measured by electrocardiogram guided readings of the femoral arterial pulse waves, using the carotid arterial pulse wave as the reference site. The surface distances were measured from the suprasternal notch to the carotid and femoral measurement sites, respectively. PWV was calculated by dividing the surface distance by the pulse wave transit time, yielding m/s. PWV is considered the gold standard for arterial stiffness measurements ${ }^{107}$.

\section{Stress test}

\section{Paper II}

There are different ways of inducing psychological stress. One known method is the Trier Social Stress Test (TSST), which basically consists of a waiting period upon arrival, anticipatory speech preparation, speech performance, and verbal arithmetic performance periods, followed by one or more recovery periods ${ }^{108}$. In our study, the participants waited some minutes before entering a conference room. They were assigned a numeric figure that was produced by a random number generator, using the same figure for all the participants. The figure used was: 2367458 . The subjects had to count down at the same time as they did a puzzle for 10 minutes. During the test, they received instructions such as to change language 
between Swedish and English and to count only even or odd numbers. They were prompted to count faster and switch between the languages and way of counting several times during the test.

Salivary cortisol, blood pressure and pulse were measured before the test start and directly after the test end.

\section{SF-36}

\section{Paper IV}

QoL was investigated using separate questions from the SF-36, which measures QoL across eight different domains ${ }^{95}$ (Table 2). A single item that identifies perceived change in health is also included. In this study, the patients answered the questions in domains 5 and 7 from SF36 , i.e., emotional well-being and vitality. In these domains, the answers are graded on a scale from 1 to 6 , where 1 means "all the time" and 6 means "never". The patients were instructed to give the answer that best represented their feelings during the last 4 weeks (Table 3).

\section{Table 2. Domains in SF-36}

\begin{tabular}{|l|l|}
\hline 1. Limitations in physical activities & 5. General mental health and well-being \\
\hline $\begin{array}{l}\text { 2. Limitations in social activities due to } \\
\text { physical or emotional health }\end{array}$ & $\begin{array}{l}6 . \text { Role limitations due to emotional } \\
\text { problems }\end{array}$ \\
\hline 3. Role limitations due to physical problems & 7. Vitality (energy/fatigue) \\
\hline 4. Physical pain & 8. General health \\
\hline
\end{tabular}


Table 3 Questions from the SF-36 included in our study

\begin{tabular}{|c|c|c|c|c|c|c|}
\hline & $\begin{array}{l}\text { All the } \\
\text { time }\end{array}$ & $\begin{array}{l}\text { Most of } \\
\text { the time }\end{array}$ & $\begin{array}{l}\text { A good bit } \\
\text { of the time }\end{array}$ & $\begin{array}{l}\text { Some of } \\
\text { the time }\end{array}$ & $\begin{array}{l}\text { A little of } \\
\text { the time }\end{array}$ & $\begin{array}{l}\text { None of } \\
\text { the time }\end{array}$ \\
\hline Did you feel full of pep? & 1 & 2 & 3 & 4 & 5 & 6 \\
\hline $\begin{array}{l}\text { Have you been a very nervous } \\
\text { person? }\end{array}$ & 1 & 2 & 3 & 4 & 5 & 6 \\
\hline $\begin{array}{l}\text { Have you felt so down in the } \\
\text { dumps that nothing could cheer } \\
\text { you up? }\end{array}$ & 1 & 2 & 3 & 4 & 5 & 6 \\
\hline $\begin{array}{l}\text { Have you felt calm and } \\
\text { peaceful? }\end{array}$ & 1 & 2 & 3 & 4 & 5 & 6 \\
\hline Did you have a lot of energy? & 1 & 2 & 3 & 4 & 5 & 6 \\
\hline $\begin{array}{l}\text { Have you felt downhearted and } \\
\text { blue? }\end{array}$ & 1 & 2 & 3 & 4 & 5 & 6 \\
\hline Did you feel worn out? & 1 & 2 & 3 & 4 & 5 & 6 \\
\hline Have you been a happy person? & 1 & 2 & 3 & 4 & 5 & 6 \\
\hline Did you feel tired? & 1 & 2 & 3 & 4 & 5 & 6 \\
\hline
\end{tabular}

\section{Data analyses}

\section{Paper I}

Comparisons within and between groups were done with Student's paired and unpaired 2tailed t-test for continuous variables. Mean values and standard deviations were shown. Statistical significance refers to 2 -sided $\mathrm{P} \leq 0.05$.

Linear correlations were done according to Pearson, while analysis of RMR and lean body mass over time (three time-points) was calculated with ANOVA/repeated measures.

The SD of the difference of pair-wise RMR registrations divided by the mean value of the registrations (the precision) according to an earlier investigation by us ${ }^{11}$ was $3 \%$, which gave $80 \%$ power to detect a $5 \%$ change of RMR within any of the two groups.

Software: PASW 18.0 (SPSS Inc. Chicago, IL, USA) 


\section{Paper II}

We used Student's paired and unpaired 2-tailed t-test for comparisons within and between groups. Mean values and standard deviations are given in the text. Statistical significance was considered at the $5 \%$ level $(\mathrm{p} \leq 0.05)$.

The lower limit of detection of troponin $\mathrm{T}$ was $5 \mathrm{ng} / \mathrm{l}$, so the results were set at $2.5 \mathrm{ng} / \mathrm{l}$ in calculations of non-detectable levels. Correspondingly, serum hs-CRP that was undetectable was set as $0.15 \mathrm{mg} / \mathrm{l}$ (limit of detection $=0.3 \mathrm{mg} / \mathrm{l}$ ) in calculations.

The sample size was based on a previous trial ${ }^{109}$ with similarities to our study and it was increased $60 \%$ to have marginals for possible dropouts in our longer study.

Software: SPSS 19.0 (IBM Corporation, Somers, New York, USA).

\section{Paper III}

Linear mixed model after log transformation of data, were used to analyze the differences between the two study days. Student's paired 2-tailed t-test was used to conduct ad hoc comparisons of single time-points of interest, within and between groups, using logtransformed data. The $\mathrm{P}$ value of $\leq 0.05$ was considered to be significant.

We made power calculations to estimate the sample size based on an early study of our team $^{11}$.

Software: SPSS 19.0 (IBM Corporation, Somers, New York, USA).

\section{Paper IV}

Associations between MACE and the results of the variables in SF-36 were calculated as hazard ratios (HR), with a corresponding 95\% confidence interval (CI). Significance was set at 0.05 (2-sided). Crude HR were first calculated using univariate Cox regression analyses, and adjusted HR were then calculated with multivariate Cox regression analyses. For associations between MACE and QoL, the ordinal 6-graded scales for each item from SF-36 were analyzed as linear variables. When building the final multivariate cox regression models, manual backwards stepwise analysis was used.

Software: SPSS-27 (IBM SPSS Inc., Chicago, IL) 


\section{ETHICS}

The studies presented in this thesis were approved by the Regional Ethics Committee of Linköping and performed in accordance with the Declaration of Helsinki. Written informed consent was obtained from all participating subjects. The studies were registered at ClinicalTrials.gov database.

M 186-07: Paper I.

NCT01274078: Papers II and III.

NCT 01049737: Paper IV 


\section{RESULTS AND SPECIFIC DISCUSSION}

\section{Paper I}

\section{Body composition and intake of macronutrients}

All the participants avoided RT for half a year before the study start. They spent on average the same time in the gym, with no differences between the groups. (Occasions: extra protein: $31 \pm 2$, extra meal: $34 \pm 6, p=0.16$. Minutes: extra protein: $1982 \pm 489$, extra meal: $2324 \pm$ $489, p=0.10)$.

Both groups increased their calorie intake during the study period, but the composition of macronutrients varied. This different composition in food supplementation seems to have had diverse effects in the participants. All the participants, irrespective of the kind of supplementation they were assigned to, gained on average $3.6 \pm 2.8 \mathrm{~kg}$, with similar increases in lean body mass and muscle strength in both groups, while a statistically significant increase in body fat occurred only in the group assigned to take an extra fast-food meal when comparing within the protein group (Table 4). 
Table 4. Anthropometric data, resting metabolic rate, intake of macronutrients, leg strength and body composition before and after 3 months of resistance training.

\begin{tabular}{|c|c|c|c|c|c|c|c|}
\hline variable & $\begin{array}{c}\text { Extra } \\
\text { protein } \\
\text { baseline }\end{array}$ & $\begin{array}{l}\text { After } 3 \\
\text { months }\end{array}$ & $\begin{array}{c}p \text { for } \\
\text { changes } \\
\text { within } \\
\text { group }\end{array}$ & $\begin{array}{c}\text { Extra meal } \\
\text { baseline }\end{array}$ & $\begin{array}{l}\text { After } 3 \\
\text { months }\end{array}$ & $\begin{array}{c}p \text { for } \\
\text { changes } \\
\text { within } \\
\text { group }\end{array}$ & $\begin{array}{c}p \text { for } \\
\text { difference in } \\
\text { changes } \\
\text { between } \\
\text { groups }\end{array}$ \\
\hline Age (years) & $24.2(3.7)$ & N/A & N/A & $23.2(3.4)$ & N/A & N/A & N/A \\
\hline Weight (kg) & $75.3(7.9)$ & $78.4(8.0)$ & 0.02 & $74.9(6.1)$ & $79.0(6.7)$ & 0.001 & 0.4 \\
\hline $\mathrm{SAD}(\mathrm{cm})$ & $19.8(1.6)$ & $19.7(1.5)$ & 0.7 & $20.2(1.0)$ & $20.3(1.3)$ & 0.6 & 0.5 \\
\hline RMR (kcal/24 h) & $1791(168)$ & $1948(221)$ & 0.001 & $1782(121)$ & 1959 (154) & 0.003 & 0.7 \\
\hline Protein intake (g/day) & $95.9(24)$ & $140(29)$ & $<0.0001$ & $101(20)$ & $116(17)$ & 0.049 & 0.005 \\
\hline Total fat intake (g/day) & $91.3(25)$ & $92.1(27)$ & 0.072 & $97.7(31)$ & $121(19)$ & 0.007 & 0.008 \\
\hline Carbohydr. intake (g/day)* & $283(65)$ & $295(60)$ & 0.4 & $322(91)$ & $410(83)$ & $<0.0001$ & 0.003 \\
\hline Total body fat $(\mathrm{kg})$ & $13.6(6.6)$ & $14.6(6.4)$ & 0.072 & $11.4(5.1)$ & $13.2(4.6)$ & 0.028 & 0.4 \\
\hline Total fat-free mass (kg) & $58.6(5.2)$ & $60.7(4.6)$ & 0.003 & $60.7(3.1)$ & $62.8(3.5)$ & $<0.001$ & 1.0 \\
\hline
\end{tabular}

BMI, body mass index; SAD, sagittal abdominal diameter; RMR, Resting metabolic rate; Carbohydr., carbohydrate. *Carbohydrate intake includes saccharides

The kind of supplementation influenced variables of metabolic significance, with the extra meal group having higher levels of $\mathrm{ApoB}$, higher insulin resistance measured with HOMA, and lower QUICKI, index of insulin sensitivity. Fasting insulin levels were also higher in this group (Table 5).

Table 5. Laboratory variables before and after 3 months of resistance training

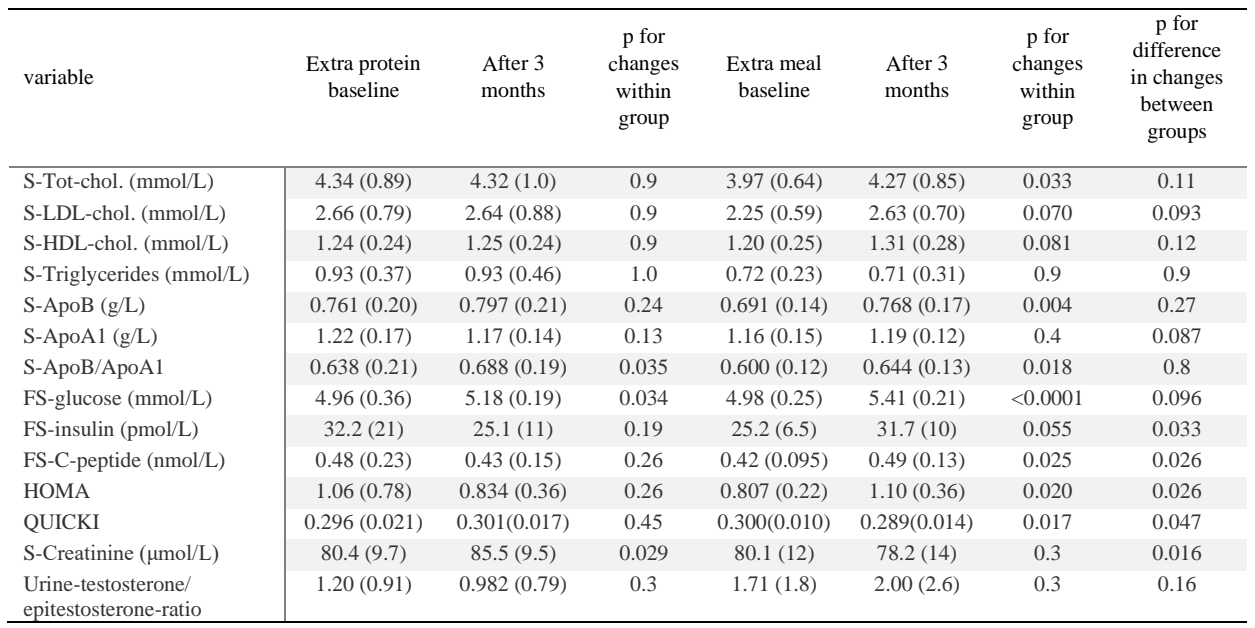

Tot, total; Homeostasis model assessment (HOMA) index of insulin resistance was calculated as: glucose concentration $x$ insulin concentration/22.5, while the Quantitative insulin sensitivity check index (QUICKI) was calculated as: $1 /[\log$ (insulin concentration) $+\log$ (glucose concentration)]. Data on urine analyses was missing in one subject of the extra protein group at the end of the study. 
Insulin's main effects are to increase glucose uptake in lean tissue and fat cells, and reduce lipolysis ${ }^{71}$, but it could also have a potential effect on human muscle tissue, inducing protein synthesis, although this effect may be related to the levels of insulin and the amino acids substrate available ${ }^{110}$. We hypothesized that inducing an increase in insulin resistance due to weight gain and diet changes could lead to higher insulin levels and consequently a building of muscle mass due to the anabolic effect of insulin. We did not find this anabolic effect, as the participants had a similar increase in lean body mass despite higher insulin levels in the extra meal group. This suggests that potential anabolic effects of insulin do not affect the RMR or muscle mass per se, but we should take into consideration that this is a pilot study with healthy young men, so it would be necessary to test this hypothesis in larger studies and in patients with criteria of metabolic syndrome, to investigate whether stronger effects may be achieved. Testing more prolonged training periods could also have a significance, as we found a trend for correlation with change of lean body mass and number of training sessions (linear regression, $\mathrm{r}=0.39, p=0.062$ ).

When trying to gain muscle mass, it is equivalent to combine RT with extra protein intake or an extra fast-food meal. However, this kind of hypercaloric and fat rich alimentation supposed a worse metabolic profile that could be harmful for cardiovascular disease in long term.

\section{$R M R$}

RMR increased in both groups after 3 months of RT (extra meal: baseline: $1782 \pm 121$, after 3 months: $1959 \pm 154 \mathrm{kcal} / 24 \mathrm{~h}$, extra protein: baseline: $1791 \pm 168$, after 3 months: $1948 \pm 221$ $\mathrm{kcal} / 24 \mathrm{~h}, p=0.003$ and $p<0.0001$ ) with significant changes already after 1 month (extra meal: $1992 \pm 119 \mathrm{kcal} / 24 \mathrm{~h}$, extra protein: $2056 \pm 232 \mathrm{kcal} / 24 \mathrm{~h}, \mathrm{p}<0.0001$, both compared with the baseline) (Fig.3). This suggests that the increase in RMR was not associated with the extra intake of fat and carbohydrates in the fast-food group, as there were no differences between the groups. However, we found a positive correlation between the number of trainings sessions and increase in RMR in all individuals (linear regression, $\mathrm{r}=0.71, p<$ 0.0001 ), a relationship that could also be seen in the change in RMR from 1 month to 3 months $(\mathrm{r}=0.58, p=0.003)$. 
Many participants achieved higher levels of RMR at 1 month than at 3 months. We could not study the possible mechanism behind this effect, but we may expect that the participants, who had not performed any kind of RT for at least 6 months before study start, experienced more exhausting exercise during the first weeks, supporting our findings of a positive correlation between number of trainings sessions and change in RMR.
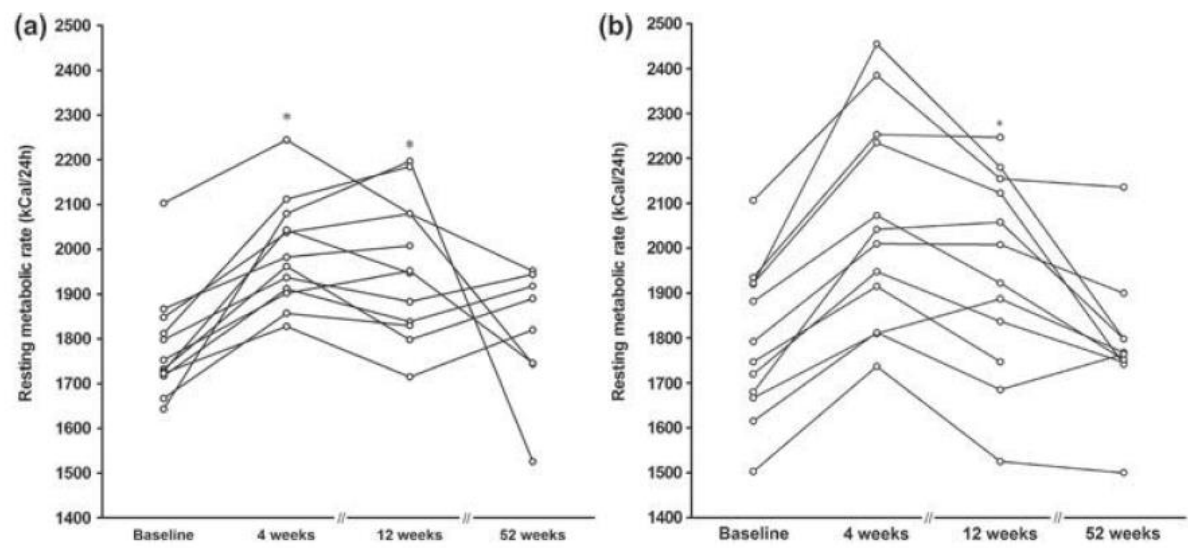

Figure 3. Change in resting metabolic rate. Individual levels of resting metabolic rate $(\mathrm{kCal} / 24 \mathrm{~h})$ in the participants from baseline to the long-term follow-up at 12 months in the two groups, (a) extra meal, (b) extra protein. * Denotes statistical difference compared with the baseline within the group. The changes in levels of RMR from baseline to that at 1 and 3 months were similar in both groups $(p=0.27$ by analysis of repeated measures).

RMR per kg lean body mass was higher after 3 months of RT (total material before $30.0 \pm 2.4$ $\mathrm{kcal} / \mathrm{kg}$, after: $31.6 \pm 2.2 \mathrm{kcal} / \mathrm{kg}, p=0.003$ in paired t-test) independent of protein or extra meal intake (all $\mathrm{p}>0.5$ ). This increase in RMR per kg lean body mass was related to the increase in body fat content (linear regression analysis $\mathrm{r}=0.42, p=0.04$ ), which is in line with early findings showing a correlation between energy expenditure in muscle and amount of fat tissue ${ }^{111}$.

In our study, we can see that only 12 weeks of RT increased RMR as a consequence of a higher RMR per kg lean body mass and an increase in muscle tissue. This can be explained by the increased energy requirement per weight unit of muscle tissue at rest. 


\section{Long-term follow up}

Lean body mass, body weight and total fat returned to baseline after 12 months despite 9 of the 19 participants in the long-term follow up continuing to perform RT with different intensities.

We did not find any differences between RMR per kg lean body mass at baseline and after 1 year (baseline $30.3 \pm 2.6$, long-term: $30.5 \pm 2.0 \mathrm{kcal} / \mathrm{kg}, p=0.6, \mathrm{n}=19$ ), but we found a strong statistically significant correlation between the change of RMR and the corresponding change in lean body mass $(\mathrm{r}=0.70, p=0.001, \mathrm{n}=19)$, which is in line with our conclusions explained above, expecting a decrease in RMR when the participants lost muscle mass due to the lower or interrupted RT. This effect could be enhanced by the fact that all the participants were men and they are affected by larger losses of muscle mass in response to detraining than women $^{112}$.

So, it seems to be necessary to maintain over time high intensity and regularity in RT sessions to achieve and preserve the benefits of this form of exercise. 


\section{Paper II}

\section{Results in mixed population: with and without blueberries}

\section{Metabolic findings}

When looking at the results in the mixed population, i.e. without separating the groups by consumers or not of blueberries (Table 6), we found interesting results from a cardiovascular point of view, in line with results published before ${ }^{113} 109$. Levels of insulin and triglycerides diminished, and HDL cholesterol increased after the period of regular exercise when compared with the period of minimal physical activity. We observed a favorable metabolic effect of exercise, with improved insulin sensitivity and an ameliorated lipid profile when compared with sedentarism.

\section{Changes in levels of Inflammation}

There was an increase in inflammation measured by hs-CRP after the running-races when analyzing all races (hs-CRP before race $0.49 \pm 0.7 \mathrm{mg} / \mathrm{l}$; after $0.58 \pm 0.7 \mathrm{mg} / 1, P=0.017$ ). However, hs-CRP tended to be lower after the race performed after the 4 weeks of exercise compared with the period of minimal physical activity (Table 6). hs-CRP is not specific for muscle mass, but at least part of it should come from the big muscle groups involved in the runs, and it would explain a tendency toward lower hs-CRP after 4 weeks of regular training, when the participants become more fit and improve their race times. It has been shown before that intense physical exercise induces an inflammatory response with increased CRP in the acute phase ${ }^{59}$ and that intensive and regular training that is maintained over time may have a systemic anti-inflammatory effect ${ }^{64}$. Our results follow the same line, with the particularity that they are related to a more common way of training that is performed by regular people, in contradistinction to elite or professional athletes.

\section{Troponin T}

Troponin $\mathrm{T}$ is associated with structural heart disease and subsequent risk of death even in subjects without typical symptoms of ischemia ${ }^{67}$, and is used in clinical practice as a marker 
of CVD. In our results, troponin T was present at a detectable level after 51 out of the total 112 running-races $(45.5 \%)$ in the study, 7 of which $(6.2 \%)$ were above the reference limit of $14 \mathrm{ng} / \mathrm{l}$. Among participants who ran at least two running-races, $75 \%$ showed detectable troponin $\mathrm{T}$ levels in plasma after at least one race, with no differences between the groups. However, we found a reduction in post-race troponin $\mathrm{T}$ after the exercise period in women, when they were fitter (Table 6). It is well known that troponin T may elevate after strenuous physical activity ${ }^{65,67}$, but this phenomenon is not so widely investigated in other, more commonly performed, forms of physical activity ${ }^{114}$. Thus, we should take these results into consideration when making a clinical evaluation of acute chest pain and presence of troponin T.

Table 6. Laboratory variables and body fat content during the trial in the mixed population, i.e., without separate analysis depending on whether blueberries were consumed or not, $n=26$. All laboratory variables, except hs-CRP, were the mean of the analyses before and after the $5 \mathrm{~km}$ race that was performed at the beginning and at the end of both trial periods, i.e., the period of exercise or the period of minimal physical activity. There were no differences between the groups at baseline, i.e., baseline of exercise compared with the baseline of exercise periods. $P$ values correspond to Student's paired 2-tailed $t$-test. The delta value is the level of a measurement at the end of the period minus the corresponding level at baseline for the same period.

\begin{tabular}{|c|c|c|c|c|c|c|}
\hline variable & $\begin{array}{l}\text { Baseline } \\
\text { before } \\
\text { exercise } \\
\text { period }\end{array}$ & $\begin{array}{c}\text { After } 4 \text { weeks of } \\
\text { exercise }\end{array}$ & $\begin{array}{l}\text { Baseline before } \\
\text { minimal } \\
\text { physical activity } \\
\text { period }\end{array}$ & $\begin{array}{c}\text { After } 4 \text { weeks of } \\
\text { minimal } \\
\text { physical activity }\end{array}$ & $\begin{array}{l}\mathrm{P} \text { for difference } \\
\text { between the end } \\
\text { of the two } \\
\text { periods }\end{array}$ & $\begin{array}{l}\mathrm{P} \text { for difference } \\
\text { of delta values } \\
\text { between the two } \\
\text { periods }\end{array}$ \\
\hline \multicolumn{7}{|c|}{ Body fat (kg) } \\
\hline All & - & $14.4 \pm 8.3$ & - & $14.4 \pm 8.4$ & 0.8 & - \\
\hline Women & - & $19.1 \pm 7.7$ & - & $19.3 \pm 7.8$ & 0.43 & - \\
\hline Men & - & $11.5 \pm 7.5$ & - & $11.3 \pm 7.4$ & 0.26 & - \\
\hline \multicolumn{7}{|c|}{ S-HDL-chol (mmol/l) } \\
\hline All & $1.50 \pm 0.34$ & $1.55 \pm 0.38$ & $1.50 \pm 0.36$ & $1.50 \pm 0.35$ & 0.003 & 0.039 \\
\hline Women & $1.70 \pm 030$ & $1.76 \pm 0.33$ & $1.70 \pm 0.34$ & $1.73 \pm 0.32$ & 0.13 & 0.34 \\
\hline Men & $1.34 \pm 0.28$ & $1.43 \pm 0.36$ & $1.35 \pm 0.30$ & $1.34 \pm 0.29$ & 0.017 & 0.071 \\
\hline \multicolumn{7}{|c|}{ S-triglycerides $(\mathrm{mmol} / \mathrm{l})$} \\
\hline All & $0.94 \pm 0.41$ & $0.88 \pm 0.31$ & $0.91 \pm 0.56$ & $1.0 \pm 0.45$ & 0.046 & 0.036 \\
\hline Women & $0.71 \pm 0.29$ & $0.70 \pm 0.29$ & $0.72 \pm 0.23$ & $0.85 \pm 0.35$ & 0.056 & 0.27 \\
\hline Men & $1.1 \pm 0.40$ & $0.99 \pm 0.27$ & $1.1 \pm 0.69$ & $1.1 \pm 0.48$ & 0.20 & 0.087 \\
\hline \multicolumn{7}{|c|}{ FS-insulin (pmol/l) } \\
\hline All & $57 \pm 25$ & $49 \pm 17$ & $54 \pm 17$ & $58 \pm 17$ & 0.015 & 0.009 \\
\hline Women & $54 \pm 25$ & $49 \pm 20$ & $58 \pm 19$ & $62 \pm 17$ & 0.16 & 0.14 \\
\hline Men & $59 \pm 26$ & $49 \pm 16$ & $51 \pm 16$ & $55 \pm 17$ & 0.044 & 0.038 \\
\hline \multicolumn{7}{|c|}{ Hs-CRP before race (mg/l) } \\
\hline All & $0.49 \pm 0.59$ & $0.42 \pm 0.51$ & $0.46 \pm 0.52$ & $0.58 \pm 0.94$ & 0.28 & 0.48 \\
\hline Women & $0.63 \pm 0.56$ & $0.56 \pm 0.70$ & $0.68 \pm 0.72$ & $0.74 \pm 1.1$ & 0.41 & 0.91 \\
\hline Men & $0.38 \pm 0.61$ & $0.35 \pm 0.39$ & $0.32 \pm 0.31$ & $0.52 \pm 0.88$ & 0.46 & 0.45 \\
\hline \multicolumn{7}{|c|}{ Hs-CRP after race (mg/l) } \\
\hline All & $0.63 \pm 0.58$ & $0.45 \pm 0.54$ & $0.57 \pm 0.62$ & $0.72 \pm 0.86$ & 0.054 & 0.19 \\
\hline Women & $0.73 \pm 0.59$ & $0.59 \pm 0.79$ & $0.82 \pm 0.82$ & $1.2 \pm 1.2$ & 0.058 & 0.48 \\
\hline Men & $0.56 \pm 0.59$ & $0.37 \pm 0.35$ & $0.41 \pm 0.42$ & $0.48 \pm 0.47$ & 0.47 & 0.27 \\
\hline \multicolumn{7}{|c|}{ Troponin $\mathrm{T}$ after race (ng/l) } \\
\hline All & $7.1 \pm 5.7$ & $5.3 \pm 3.3$ & $6.4 \pm 6.7$ & $5.2 \pm 4.8$ & 0.96 & 0.92 \\
\hline Women & $6.8 \pm 5.4$ & $5.0 \pm 2.5$ & $3.6 \pm 2.1$ & $3.4 \pm 1.8$ & 0.038 & 0.68 \\
\hline Men & $7.2 \pm 6.1$ & $5.4 \pm 3.7$ & $8.3 \pm 8.1$ & $6.3 \pm 5.6$ & 0.53 & 0.86 \\
\hline
\end{tabular}

Chol = cholesterol; $\mathbf{C K}$ = creatine kinase; FS = fasting serum; hs-CRP = high-sensitivity C-reactive protein; $\mathbf{S}=$ serum. 


\section{Acute effects of a single $5 \mathrm{~km}$ race}

We compared the metabolic markers sampled at fasting state on the morning of the race with the morning after, and found that glucose levels were lowered by the races (data from all running-races accumulated, levels before $5.28 \pm 0.44 \mathrm{mmol} / 1$; after $5.11 \pm 0.39 \mathrm{mmol} / 1, p<$ 0.0001), while corresponding insulin levels did not show a statistically significant change, although insulin levels tended to diminish after the race (levels before $56 \pm 23 \mathrm{pmol} / \mathrm{l}$; after 53 $\pm 25 \mathrm{pmol} / \mathrm{l}, p=0.13$ ). Our results are in line with previous finds showing that exercise increases glucose uptake in skeletal muscle due to increase of adenosine monophosphate (AMP), which can induce insulin-dependent glucose uptake in fat and lean body mass ${ }^{115}$.

Triglyceride levels also decreased the morning after a running-race (levels before $0.99 \pm$ $0.52 \mathrm{mmol} / \mathrm{l}$; after $0.88 \pm 0.45 \mathrm{mmol} / \mathrm{l}, P=0.008$ ), while levels of HDL cholesterol or LDL cholesterol did not change significantly.

\section{Effects of adding blueberries to the diet during the exercise period}

\section{Lipids}

The participants who were randomized to consume $150 \mathrm{~g}$ of blueberries every exercise day experienced metabolic changes as shown in table 7. Triglyceride levels were unchanged in the blueberry group, while they diminished in the control group, suggesting that the berries may have influenced triglyceride levels in some way. However, blueberries seemed to have a positive effect on lipids, with this group having lower levels of ApoB, higher HDL and lower LDL cholesterol after 3 months of exercise when consuming blueberries. Our findings are in line with early observations in which consumption of mixed types of berries for 8 weeks resulted in an improved lipid profile, including also favorable changes in platelet function and blood pressure ${ }^{78}$.

\section{Glucose}

The berries induced an increase in fasting glucose (levels before exercise period: $5.12 \pm 0.49$, levels after 4 weeks of exercise: $5.32 \pm 0.29, \mathrm{p}=0.082$ ) despite exercise and its known positive effect in glucose metabolism. The difference in changes between the blueberries and the control group was statistically significant $(\mathrm{p}=0.044)$. (Table 7$)$. It has been suggested that 
physical activity increases insulin sensitivity not only by enhancing expression of glucose transporters and other mechanisms, but also by promoting endogen oxidation which in turn increases insulin sensitivity and causes an adaptive response promoting endogenous antioxidation. Ristow et al. ${ }^{109}$ showed that exercise increased insulin sensitivity, but this beneficial effect of training could be hindered by the intake of added antioxidants such as vitamins. We hypothesize that this could be a possible explanation of our results, as well as the possibility of indirect effects when consuming the blueberries, as we did not have control over the way they were consumed. The participants reported that they added the blueberries to smoothies, yogurt, etc. containing extra sugar.

In the study by Erlund et $\mathrm{al}^{78}$, where the participants were not included in a training group, and they consumed the berries whole or pressed without mixing with other alimentary components, the same unfavorable effects on glucose metabolism were not observed, which supports our theory about the indirect effect of concomitant food intake.

\section{Troponin T}

The levels of post-race troponin $\mathrm{T}$ diminished after the 4 weeks of periodic training in the group randomized to blueberry intake (blueberries: baseline: $8.6 \pm 4.7$, after 4 weeks: $4.7 \pm$ 2.8, $p=0.029$ ), while troponin T remained unchanged in the control group. This finding could be interpreted as blueberries possibly having a cardioprotective effect, in contrast with the more unfavorable glucose outcome, but this result should be interpreted carefully due to the small sample size and the possible indirect effects of the berry intake. It is still an interesting finding that is worthy of further investigation.

Table 7. Change in fasting levels of laboratory variables in the groups when comparing the 4-week exercise period with $(n=13)$, or without $(n=13)$, intake of blueberries. Delta values denote difference from baseline to the end of the period.

\begin{tabular}{|c|c|c|c|c|c|}
\hline variable & Supplement & $\begin{array}{l}\text { Baseline before } \\
\text { exercise period }\end{array}$ & $\begin{array}{c}\text { After } 4 \text { weeks of } \\
\text { exercise }\end{array}$ & $\begin{array}{l}\mathrm{P} \text { for difference } \\
\text { within groups }\end{array}$ & $\begin{array}{c}\text { P for group } \\
\text { difference of delta } \\
\text { values }\end{array}$ \\
\hline S-LDL-chol (mmol/l) & Blueberries & $2.86 \pm 0.73$ & $2.67 \pm 0.80$ & 0.037 & 0.13 \\
\hline \multirow[t]{2}{*}{ S-HDL-chol (mmol/l) } & Blueberries & $1.51 \pm 0.29$ & $1.64 \pm 0.33$ & 0.006 & \multirow{2}{*}{0.088} \\
\hline & Control & $1.43 \pm 0.39$ & $1.47 \pm 0.42$ & 0.20 & \\
\hline S-triglycerides $(\mathrm{mmol} / \mathrm{l})$ & Blueberries & $0.81 \pm 0.28$ & $0.83 \pm 0.30$ & 0.87 & 0.072 \\
\hline S-ApoB (g/l) & Control & $0.86 \pm 0.21$ & $0.85 \pm 0.20$ & 0.77 & 0.20 \\
\hline \multirow[t]{2}{*}{ FS-glucose $(\mathrm{mmol} / \mathrm{l})$} & Blueberries & $5.12 \pm 0.49$ & $5.32 \pm 0.29$ & 0.082 & \multirow{2}{*}{0.044} \\
\hline & Control & $5.24 \pm 0.27$ & $5.17 \pm 0.23$ & 0.35 & \\
\hline \multirow[t]{2}{*}{ Troponin $\mathrm{T}$ after race (ng/l) } & Blueberries & $8.6 \pm 4.7$ & $4.7 \pm 2.8$ & 0.029 & \multirow{2}{*}{0.058} \\
\hline & Control & $5.6 \pm 6.4$ & $5.6 \pm 3.7$ & 0.97 & \\
\hline FS-Insulin (pmol/l) & Blueberries & $51 \pm 24$ & $43 \pm 15$ & 0.13 & 0.47 \\
\hline
\end{tabular}

Chol = cholesterol; FS = fasting serum; $\mathrm{S}=$ serum. 


\section{Paper III}

\section{Glucose-insulin-cortisol}

We found our results in Paper II very interesting and we wanted to study in more depth how a single race at maximal speed could affect metabolic variables such as glucose, insulin, cortisol, RMR and troponin T. In this study, the measurements of the different variables were taken in direct relation to the race, in contrast with our previous study, allowing for more detailed observations.

Although glucose levels were basically unchanged on the race day when comparing the mean of the values with the resting day, we observed an acute effect of the race on plasma glucose levels, which increased significantly directly after the race (baseline: $5.01 \pm 0.37$ $\mathrm{mmol} / \mathrm{l}$, post-race: $6.36 \pm 1.3 \mathrm{mmol} / \mathrm{l} . p<0.0001$, range post-race from 4.9 to $9.9 \mathrm{mmol} / \mathrm{l}$ ), and were also higher when compared with the same time-point on the resting day $(6.36 \pm 1.3$ $\mathrm{mmol} / \mathrm{l}$ vs $4.88 \pm 0.59 \mathrm{mmol} / \mathrm{l}, \mathrm{p}=0.001$ ). (Table 8 . Fig. 4).

Insulin levels were increased about two-fold by the race (baseline: $42 \pm 21$, after race: $90 \pm$ 54; $p=<0.0001$ ), being also higher compared with the same time-point on the non-exercise day $(p<0.0001)$ and maintaining generally higher levels during the whole running day $(p<$ 0.0001) (Table 8. Fig. 5).

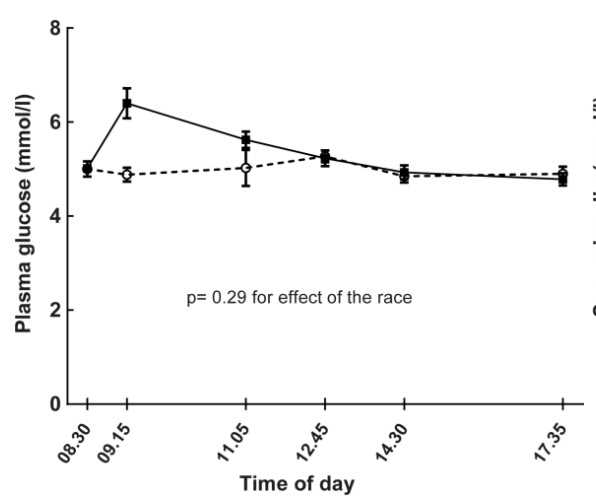

Fig 4. Effects of running (continuous line) $5 \mathrm{~km}$ on plasma glucose levels compared with a nonexercise day (dashed line) in 17 healthy subjects. The running took place after the baseline test on the day of the run. Data are means and SE. Linear mixed model for estimating the effects of the race: $\mathbf{p}=\mathbf{0 . 2 9}$.

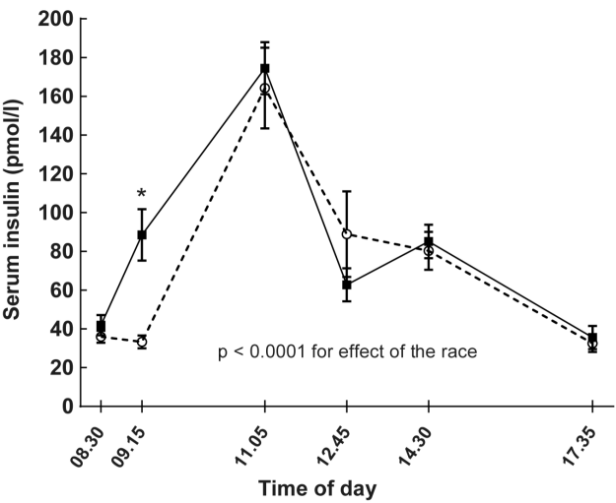

Fig 5. Effects of running $5 \mathrm{~km}$ (continuous line) on serum insulin levels compared with a non-exercise day (dashed line) in 17 healthy subjects studied on two separate occasions. Running took place after the baseline test on the day of the run. Data are means and bars reflect SEM. Linear mixed model for estimating the effects of the race: $p<0.0001$. Serum insulin levels increased after the race on the race-day, ${ }^{*} \mathrm{p}<0.0001$. 
Correspondingly, insulin sensitivity measured by QUICKI followed the same pattern, and was reduced on the running day compared with the non-exercise day $(p<0.0001)$ with a significant reduction directly after the race compared with the baseline $(p<0.0001)$ (Table 8. Fig. 6). This could explain why glucose levels were higher after exercise despite a parallel increase in insulin, suggesting that it was lower insulin sensitivity and not a lack of insulin that was behind this phenomenon.

Insulin sensitivity may be affected by different hormones, such as growth hormone (GH), insulin-like growth factor type 1 (IGF-1) and cortisol. We decided to follow cortisol, as it is possible to measure it in saliva by collecting salivary samples in a simple way at home, which gave us the possibility to record values at night and directly after waking up. Both serum and salivary cortisol were higher on the day that started with a race (Table 8. Fig. 7), even in the last measurements in the evening and before going to bed (rest-day: $1.58 \pm 1.1 \mathrm{nmol} / \mathrm{l}$, raceday: $2.22 \pm 1.0 \mathrm{nmol} / 1, \mathrm{p}=0.015$ ). These values normalized during the night and there were no differences with the resting group on the morning after the study day (rest-day: $16.0 \pm 5.5$ nmol/l, race-day: $14.5 \pm 5.3 \mathrm{nmol} / \mathrm{l}, \mathrm{p}=0.32$ ).

A hypothesis that could be behind these results is that the increased activity in the hypothalamic-pituitary-adrenal axis (HPA-axis) due to the exercise, resulted in higher cortisol levels that could affect insulin sensitivity, as both serum cortisol and serum insulin were correlated when taken at the same time after the race. Unfortunately, we did not measure other stress hormones that may be elevated by exercise, such as catecholamines, but we assume that they were a contributing factor to the higher glucose levels after exercise, as these hormones are known to have an hyperglycemic effect and they increase as a response to stress and exercise ${ }^{116,117}$.

We expect, as well, an increase in GH secretion as a response to exercise ${ }^{118}$ with a direct and indirect effect through the IGF-1 system in the glucose metabolism ${ }^{119}$. GH contributes to insulin resistance and increases IGF-1 production. Unlikely, IGF-1 has insulin-like effects and increases insulin sensitivity under the influence of $\mathrm{GH}$ and insulin ${ }^{120}$, so one may hypothesize that the effect of IGF-1 could compensate for the initial response to the exercise, with higher glucose and insulin levels, and contribute to regulating and normalizing glucose levels during the day. 

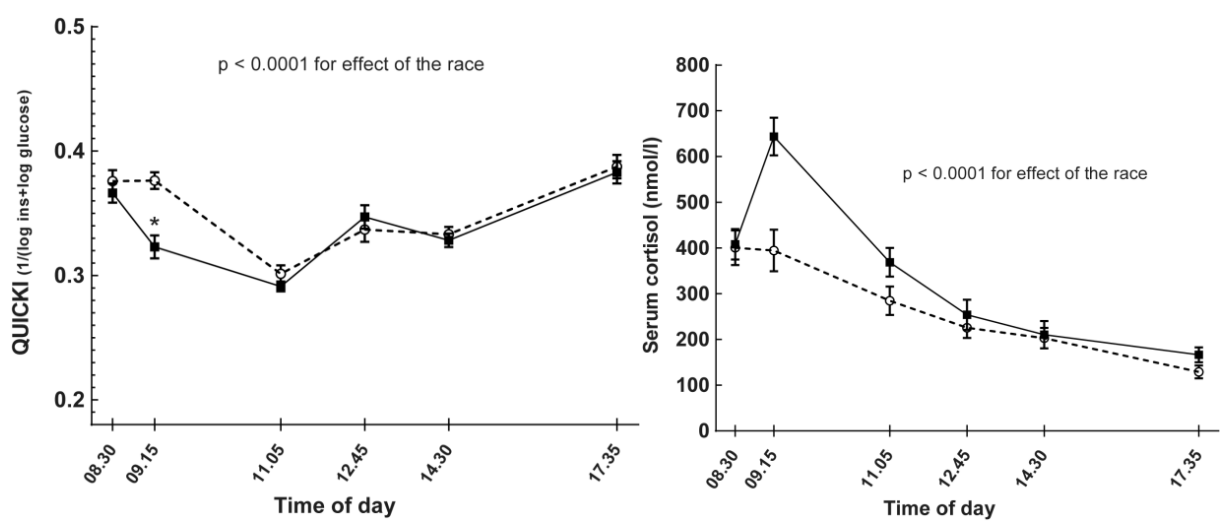

Fig 6. Effects of running $5 \mathrm{~km}$ (continuous line) on insulin sensitivity by QUICKI index 1/(log10insulin +log10glucose) compared with a non-exercise day (dashed line) in 17 healthy subjects studied on two separate occasions. Running took place after the baseline test on the day of the run. Data are means and standard errors. Linear mixed model for analyzing the effect of the race compared with the day of rest: $p<$ 0.0001. *corresponds to $\mathrm{p}<0.0001$ when comparing QUICKI index before and after the race on the day of the race.

Fig 7. Effects of running $5 \mathrm{~km}$ (continuous line) on serum cortisol levels compared with a day without exercise (dashed line) in 17 healthy subjects. Running took place after the baseline test on the day of the run. Data are means and standard errors. Linear mixed model for estimating effects of the race: $p<0.0001$.

\section{Effects of the race on the metabolic rate}

RMR measured with indirect calorimetry increased quite directly after the race, compared with same time-point on the resting day (rest-day: $2044 \pm 247 \mathrm{kcal} / 24 \mathrm{~h}$, race-day: $2245 \pm 310$ $\mathrm{kcal} / 24 \mathrm{~h}, \mathrm{p}<0.0001$ ), while it normalized during the day. We hypothesized that this phenomenon could be explained by the increase in cortisol levels after the race, as it is known that hypercortisolemia increases energy expenditure, and that hypocortisolemia lowers $\operatorname{RMR}^{121,122}$.

\section{Effects of the race on Troponin $T$}

No troponin $\mathrm{T}$ was detectable at baseline or directly after the race, but we found elevated levels of troponin $\mathrm{T}$ after only a few hours, with the highest mean values before lunch, where 12 of the 17 participants had detectable levels of troponin $\mathrm{T}$ at this time-point. When taking new samples the next day, there was still one participant with detectable levels of troponin $\mathrm{T}$ (5 ng/l) (Table 8. Fig. 8). 
ECGs were recorded after the races, but they did not show any pathological results. It is difficult to assess the clinical significance of having detectable troponin $\mathrm{T}$ levels, but there were two individuals who showed dynamics in troponin T release with high levels: 32 and 27 $\mathrm{ng} / \mathrm{l}$ respectively, which are clearly above the limit that is considered clinically pathological $(15 \mathrm{ng} / \mathrm{l})$ and could be interpreted as myocardial injury, making our results especially interesting.

When working in clinical practice, troponin $\mathrm{T}$ is a common biomarker used to identify myocardial injury, not only of necrotic character, but also as a marker for heart strain secondary to other pathological states such as infections and embolism ${ }^{123}$. It is well known that strenuous exercise may lead to different heart pathologies and exercise-induced troponin $\mathrm{T}$ release $\mathrm{e}^{124,125}$, but in our study, the participants were running a distance of only $5 \mathrm{~km}$, which is a very common way of training in nonprofessional athletes, so we should think about the possibility that a patient might have been running before when evaluating possible elevated troponin $\mathrm{T}$ levels in clinical praxis.

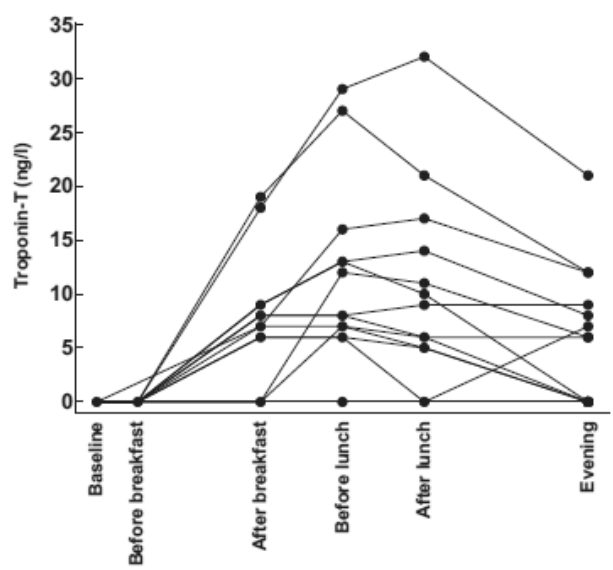

Fig 8. Effects of running $\mathbf{5 m}$ on troponin $\mathrm{T}$ in 17 healthy subjects. Individual consecutive changes in troponin $\mathrm{T}$ are displayed by the aligned filled circles. Undetectable levels were set as zero in the graph. 
Table 8. Laboratory data during a day without exercise and a day which started with running $5 \mathrm{~km}$ at maximal speed $(\mathrm{n}=17$ participants). Data are mean values and (SD). Comparisons of data from the race-day with the day of rest was done with a linear mixed model. Troponin $T$ that was not detectable (limit of detection $5 \mathbf{n g} / \mathbf{m l}$ ) was set as zero in calculations.

\begin{tabular}{|c|c|c|c|c|c|c|c|c|}
\hline variable & $\begin{array}{l}\text { Rest or } \\
\text { race }\end{array}$ & Baseline & $\begin{array}{l}\text { Before } \\
\text { breakfast }\end{array}$ & $\begin{array}{l}\text { After } \\
\text { breakfast }\end{array}$ & $\begin{array}{l}\text { Before } \\
\text { lunch }\end{array}$ & $\begin{array}{l}\text { After } \\
\text { lunch }\end{array}$ & Evening & $\begin{array}{l}\text { Plinear } \\
\text { mixed } \\
\text { model }\end{array}$ \\
\hline \multirow[t]{2}{*}{$\begin{array}{l}\text { Plasma glucose } \\
(\mathrm{mmol} / \mathrm{l})\end{array}$} & Rest & $5.00(0.68)$ & $4.88(0.59)$ & $5.02(1.6)$ & $5.27(0.52)$ & $4.85(0.55)$ & $4.90(0.62)$ & \multirow[t]{2}{*}{0.29} \\
\hline & Race & $5.01(0.37)$ & $6.36(1.3)$ & $5.62(0.73)$ & $5.23(0.69)$ & $4.93(0.60)$ & $4.78(0.54)$ & \\
\hline \multirow[t]{2}{*}{$\begin{array}{l}\text { Serum insulin } \\
(\mathrm{pmol} / \mathrm{l})\end{array}$} & Rest & $36(13)$ & 33 (14) & $164(86)$ & $91(87)$ & $78(40)$ & $34(17)$ & \multirow{2}{*}{$<0.0001$} \\
\hline & Race & $42(21)$ & $90(54)$ & $171(59)$ & $63(34)$ & 82 (39) & $36(25)$ & \\
\hline \multirow{2}{*}{$\begin{array}{l}\text { QUICKI } \\
1 /(\log 10 \text { insulin } \\
+\log 10 \text { glucose })\end{array}$} & Rest & $\begin{array}{l}0.373 \\
(0.037)\end{array}$ & $\begin{array}{l}0.376 \\
(0.028)\end{array}$ & $\begin{array}{l}0.301 \\
(0.027)\end{array}$ & $\begin{array}{l}0.338 \\
(0.040)\end{array}$ & $\begin{array}{l}0.334 \\
(0.023)\end{array}$ & $\begin{array}{l}0386 \\
(0.038)\end{array}$ & \multirow{2}{*}{$<0.0001$} \\
\hline & Race & $\begin{array}{l}0.366 \\
(0.030)\end{array}$ & $\begin{array}{l}0.326 \\
(0.037)\end{array}$ & $\begin{array}{l}0.291 \\
(0.016)\end{array}$ & $\begin{array}{l}0.350 \\
(0.039)\end{array}$ & $\begin{array}{l}0.330 \\
(0.021)\end{array}$ & $\begin{array}{l}0.383 \\
(0.038)\end{array}$ & \\
\hline \multirow[t]{2}{*}{$\begin{array}{l}\text { Serum cortisol } \\
(\mathrm{nmol} / \mathrm{l})\end{array}$} & Rest & 400 (157) & 394 (187) & 284 (129) & $226(92)$ & $203(92)$ & $129(59)$ & \multirow[t]{2}{*}{$<0.0001$} \\
\hline & Race & 408 (137) & $644(171)$ & 369 (130) & 254 (136) & $211(124)$ & $166(67)$ & \\
\hline \multirow[t]{2}{*}{$\begin{array}{l}\text { Salivary cortisol } \\
(\mathrm{nmol} / \mathrm{l})\end{array}$} & Rest & $9.45(5.4)$ & $13.5(12)$ & $7.58(4.6)$ & $4.54(1.8)$ & $4.28(2.3)$ & $2.64(0.88)$ & \multirow[t]{2}{*}{0.037} \\
\hline & Race & $11.3(4.9)$ & $24.1(10)$ & $10.9(5.4)$ & $4.89(1.9)$ & $6.03(6.4)$ & $3.28(1.1)$ & \\
\hline \multirow[t]{2}{*}{$\begin{array}{l}\text { Serum Troponin } \mathrm{T} \\
\text { (ng/l) }\end{array}$} & & & & & & & & \multirow[t]{2}{*}{ Not done } \\
\hline & Race & $0(0)$ & $0(0)$ & $5.7(6.1)$ & $8.9(8.8)$ & $8.0(9.0)$ & $4.8(6.2)$ & \\
\hline
\end{tabular}




\section{Paper IV}

The previous papers, I, II and III, were based on a randomized, interventional design with healthy participants to elucidate cardiovascular risk factors in relation to different forms of stress. This stressor in these first papers were mainly that of physical excursion and the trials of cold induced stress have been touched upon in the introduction of this thesis. To gain more clinic information on relationships between mental stress and cardiovascular disease in highrisk patients paper IV deals with patients with T2DM. The CARDIPP cohort, that has been followed for more than a decade, offered the possibility to study relationships of different senses of mental stress, or the opposite, senses of vitality, as analyzed in separate questions from SF36 questionnaire to incidence of CVD and mortality. Furthermore, the fact that the study design was prospective and observational and thus different to my previous interventional papers, was considered advantageous to achieve a more complete scientific training.

From the 761 patients with T2DM who were included in the CARDIPP, 752 answered the questions from SF-36 and remained for further analyses in this study. During a follow up period of median 11.6 years, $119(16 \%)$ patients suffered a MACE and a further $109(14 \%)$ died during the observation period.

\section{Relevant metabolic variables}

Table 9 shows the baseline characteristics of the study cohort and the results of the univariate Cox regression analysis of MACE in relation to vascular risk factors. Male sex, duration of diabetes, HbA1c, SAD, mean SBP and PWV were separately associated with MACE.

SAD has been defined before in the CARDIPP population as a more independent risk marker for prediction of arterial stiffness and a better marker for subclinical organ damage measured by intima-media thickness (IMT) and PWV, than waist circumference ${ }^{104,126,127}$. ApoB/ApoA-I ratio was significant associated with subclinical atherosclerosis, measured as carotid IMT, independent of conventional lipids and lipoproteins, CRP, glycemic control and use of statins in this cohort of T2DM patients ${ }^{128}$. PWV was also a very interesting marker of CVD in this population. PWV is the most widely used measure of arterial stiffness and clearly associated to atherosclerosis. It was strongly associated with HbA1c and predicted incident cardiovascular events independently of diabetes-specific and traditional cardiovascular risk factors like age, sex, diabetes duration, office systolic blood pressure, resting heart rate, total 
cholesterol, HbA1c, eGFR and smoking status ${ }^{129}$. The impact of high Blood pressure has also been investigated in several earlier papers from the CARDIPP cohort, finding that SBP measured ambulatory, was a predictor for left ventricular mass ${ }^{130}$, and also that circadian blood pressure variation could be a marker for subclinical cardiovascular organ damage ${ }^{131}$ and that toe brachial index was a risk marker for CVD independently of arterial stiffness in this patient group ${ }^{132}$. Additional investigations were performed with focus on circadian blood pressure variations and on masked nocturnal hypertension, which was related to increased arterial stiffness and higher central blood pressure in T2DM, even in patients with clinic blood pressure levels below the recommended limits ${ }^{106,131}$.

These earlier published paper from the CARDIPP cohort have highlighted new and traditional independent risk factors for CVD in T2DM, like carotid $\mathrm{IMT}^{128}$, masked nocturnal hypertension ${ }^{106}, \mathrm{TNFrII}^{133}$, toe brachial index ${ }^{132}, \mathrm{SAD}^{126}$, aortic $\mathrm{PWV}^{129}$, abdominal obesity $^{127}$, leptin levels ${ }^{96}, 25-\mathrm{OH}$-vitamin D3 ${ }^{134}$ and $\mathrm{PTH}^{134}$. And the main aim of the last paper of the thesis was do discern if sense of stress, or comfort, in life could serve as a risk marker that was independent of metabolic and arteriosclerotic markers of disease.

Table 9. Risk factors for MACE in T2DM patients. Baseline characteristics of the study cohort and Cox regression analyses of MACE in relation to all included vascular risk factors, as well as all items from the two domains vitality and emotional well-being in SF-36. All analyses are conducted by univariate Cox regression analyses.

\begin{tabular}{|c|c|c|c|c|c|}
\hline & MACE & \multirow{2}{*}{$\begin{array}{l}\text { No MACE } \\
\text { (mean } \pm \text { SD or percentage) }\end{array}$} & \multicolumn{3}{|c|}{ Univariate Cox regression } \\
\hline & (mean \pm SD or percentage) & & Hazard ratio & $95 \% \mathrm{CI}$ & p-value \\
\hline Male sex & $\mathrm{n}=92 / 122(75 \%)$ & $\mathrm{n}=406 / 639(64 \%)$ & 1.700 & $1.126-2.568$ & $0.012 *$ \\
\hline Age (years) & $61.0 \pm 3.2$ & $60.6 \pm 3.0$ & 1.042 & $0.982-1.107$ & 0.173 \\
\hline Duration of diabetes (years) & $9.8 \pm 7.7$ & $6.8 \pm 5.8$ & 1.049 & $1.029-1.070$ & $<0.001 * *$ \\
\hline $\mathrm{HbAlc}(\mathrm{mmol} / \mathrm{mol})$ & $57.6 \pm 11.1$ & $52.1 \pm 11.7$ & 1.029 & $1.017-1.042$ & $<0.001 * *$ \\
\hline Current smoker & $\mathrm{n}=26 / 117(22 \%)$ & $\mathrm{n}=115 / 631(18 \%)$ & 1.335 & $0.863-2.064$ & 0.194 \\
\hline $\mathrm{SAD}(\mathrm{cm})$ & $26.7 \pm 3.7$ & $25.3 \pm 3.8$ & 1.091 & $1.041-1.141$ & $<0.001 * *$ \\
\hline ApoB/ApoA1 & $0.76 \pm 0.17$ & $0.73 \pm 0.17$ & 2.489 & $0.875-7.708$ & 0.087 \\
\hline Mean SBP (mmHg) & $132 \pm 15$ & $129 \pm 13$ & 1.013 & $1.000-1.026$ & $0.044 *$ \\
\hline $\mathrm{PWV}(\mathrm{m} / \mathrm{s})$ & $11.2 \pm 2.6$ & $10.2 \pm 2.0$ & 1.182 & $1.097-1.274$ & $<0.001 * *$ \\
\hline \multicolumn{6}{|l|}{ Short Form 36: } \\
\hline \multicolumn{6}{|l|}{ Domain: Vitality } \\
\hline Seldom feeling full of pep & $3.30 \pm 1.53$ & $2.80 \pm 1.33$ & 1.252 & $1.108-1.415$ & $<0.001 * *$ \\
\hline $\begin{array}{l}\text { Seldom having a lot of } \\
\text { energy }\end{array}$ & $3.61 \pm 1.45$ & $3.08 \pm 1.35$ & 1.287 & $1.134-1.460$ & $<0.001 * *$ \\
\hline Worn out & $2.66 \pm 1.47$ & $2.23 \pm 1.30$ & 1.231 & $1.089-1.393$ & $0.001 * *$ \\
\hline Tired & $3.25 \pm 1.49$ & $2.88 \pm 1.28$ & 1.214 & $1.066-1.383$ & $0.003 * *$ \\
\hline \multicolumn{6}{|l|}{ Domain: Emotional well-being } \\
\hline Very nervous & $1.74 \pm 1.15$ & $1.56 \pm 0.89$ & 1.161 & $0.979-1.376$ & 0.086 \\
\hline Impossible to cheer up & $1.53 \pm 1.00$ & $1.43 \pm 0.86$ & 1.096 & $0.910-1.319$ & 0.335 \\
\hline Seldom calm and peaceful & $2.66 \pm 1.49$ & $2.46 \pm 1.37$ & 1.097 & $0.969-1.240$ & 0.142 \\
\hline Downhearted and blue & $1.86 \pm 1.06$ & $1.65 \pm 0.97$ & 1.186 & $1.014-1.388$ & $0.033 *$ \\
\hline Seldom happy & $3.00 \pm 1.46$ & $2.63 \pm 1.23$ & 1.213 & $1.062-1.386$ & $0.004 * *$ \\
\hline
\end{tabular}

CI: confidence interval, SAD: sagittal abdominal diameter, SBP: systolic blood pressure, PWV: pulse wave velocity, SF-36: short form $36, *=p<0.05, * *=p<0.005$. 


\section{SF-36}

All items in the vitality domain in SF-36: "seldom feeling full of pep", "seldom having a lot of energy", "feeling worn out", and "feeling tired", and two items from the emotional wellbeing domain: "downhearted and blue" and "seldom feeling happy" were separately associated with MACE as shown in table 9.

When analyzing the items from SF-36 in relation to MACE in multivariate Cox regression models and adjusted for sex, age, duration of diabetes, HbA1c, smoking status, SAD, ApoB/ApoA1, SBP and PWV, there were three items from the vitality domain that remained independently associated with MACE: "seldom feeling full of pep", "seldom having a lot of energy", and "worn out", and one item from the emotional well-being domain: "seldom happy". We performed a dichotomization of all the items from SF-36 by splitting each item in the middle, where answer options 1-3 (all of the time - most of the time - a good bit of the time) were compared with answer options 4-6 (some of the time - a little bit of the time none of the time). After this dichotomization, we conducted a new multivariate Cox regression, also adjusted for the same vascular risk factors as before, and found that "seldom feeling full of pep", "seldom having a lot of energy" and "seldom happy" remained as statistically significant predictors for MACE (Table 10. Fig.9). 
Table 10. Hazard ratios for MACE in relation to dichotomized sense of vitality and emotional well-being. Cox regressions of MACE in relation to dichotomized items from the two domains vitality and emotional well-being in SF36. The dichotomization was performed by splitting each included variable in the middle, where answer options 1-3 (all of the time - most of the time - a good bit of the time) were compared with answer options 4-6 (some of the time a little bit of the time - none of the time). In the multivariate Cox regression models, all results were adjusted for sex, age, duration of diabetes, HbA1c, smoking status, sagittal abdominal diameter, ApoB/ApoA1, systolic blood pressure and pulse wave velocity.

\begin{tabular}{|c|c|c|c|c|c|c|c|c|}
\hline \multirow[t]{2}{*}{ Short Form 36} & \multirow[t]{2}{*}{ MACE } & \multirow[t]{2}{*}{ No MACE } & \multicolumn{3}{|c|}{ Univariate Cox regression } & \multicolumn{3}{|c|}{ Multivariate Cox regression } \\
\hline & & & $\begin{array}{l}\text { Hazard } \\
\text { ratio }\end{array}$ & $95 \% \mathrm{CI}$ & p-value & $\begin{array}{l}\text { Hazard } \\
\text { ratio }\end{array}$ & $95 \% \mathrm{CI}$ & $\mathrm{p}$-value \\
\hline \multicolumn{9}{|l|}{ Domain 5 (vitality) } \\
\hline $\begin{array}{l}\text { Seldom feeling full of } \\
\text { pep }\end{array}$ & $\mathrm{n}=52 / 118(44 \%)$ & $\mathrm{n}=181 / 627(29 \%)$ & 1.807 & $1.256-2.599$ & $0.001 * *$ & 1.800 & $1.134-2.856$ & $0.013^{*}$ \\
\hline $\begin{array}{l}\text { Seldom having a lot } \\
\text { of energy }\end{array}$ & $\mathrm{n}=63 / 119(53 \%)$ & $\mathrm{n}=228 / 630(36 \%)$ & 1.876 & $1.309-2.689$ & $0.001 * *$ & 1.840 & $1.165-2.905$ & $0.009 * *$ \\
\hline Worn out & $\mathrm{n}=35 / 119(29 \%)$ & $\mathrm{n}=110 / 629(18 \%)$ & 1.911 & $1.288-2.836$ & $0.001 * *$ & 1.649 & $0.994-2.737$ & 0.053 \\
\hline Tired & $\mathrm{n}=47 / 119(40 \%)$ & $\mathrm{n}=187 / 632(30 \%)$ & 1.520 & $1.053-2.196$ & $0.026 *$ & 1.288 & $0.806-2.059$ & 0.289 \\
\hline \multicolumn{9}{|l|}{$\begin{array}{l}\text { Domain } 7 \text { (emotional } \\
\text { well-being) }\end{array}$} \\
\hline Very nervous & $\mathrm{n}=12 / 118(10 \%)$ & $\mathrm{n}=33 / 630(5 \%)$ & 1.760 & $0.969-3.197$ & 0.063 & 1.511 & $0.721-3.165$ & 0.274 \\
\hline Impossible to cheer up & $\mathrm{n}=8 / 117(7 \%)$ & $\mathrm{n}=25 / 622(4 \%)$ & 1.516 & $0.739-3.108$ & 0.256 & 1.772 & $0.798-3.932$ & 0.160 \\
\hline $\begin{array}{l}\text { Seldom calm and } \\
\text { peaceful }\end{array}$ & $\mathrm{n}=32 / 119(27 \%)$ & $\mathrm{n}=141 / 632(22 \%)$ & 1.264 & $0.842-1.895$ & 0.258 & 1.149 & $0.661-1.997$ & 0.623 \\
\hline Downhearted and blue & $\mathrm{n}=13 / 119(11 \%)$ & $\mathrm{n}=37 / 630(6 \%)$ & 1.771 & $0.995-3.151$ & 0.052 & 1.290 & $0.544-3.059$ & 0.564 \\
\hline Seldom happy & $\mathrm{n}=41 / 119(35 \%)$ & $\mathrm{n}=153 / 629(24 \%)$ & 1.548 & $1.061-2.260$ & $0.023^{*}$ & 1.683 & $1.033-2.743$ & $0.037^{*}$ \\
\hline
\end{tabular}

CI: Confidence interval, $*=\mathbf{p}<0.05, * *=p<0.005$ 
A

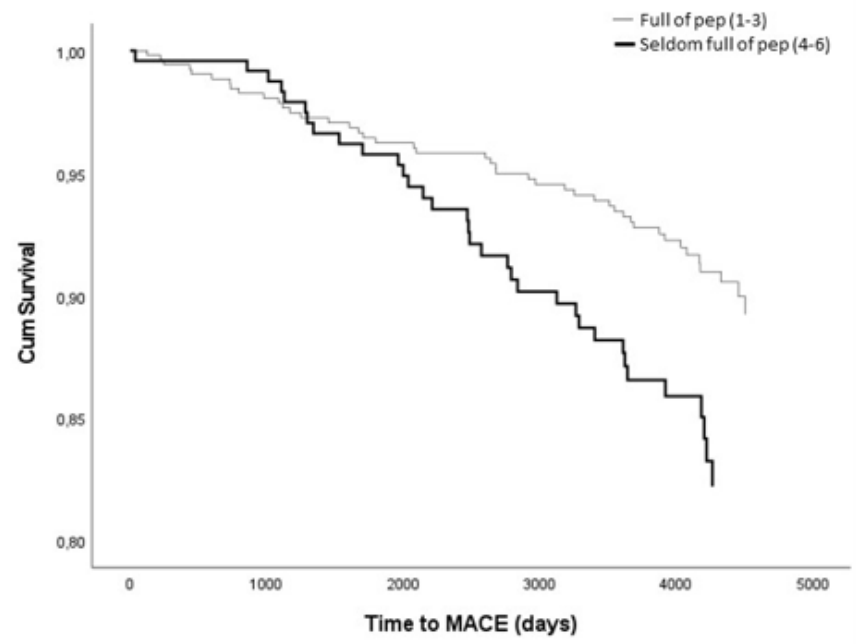

B

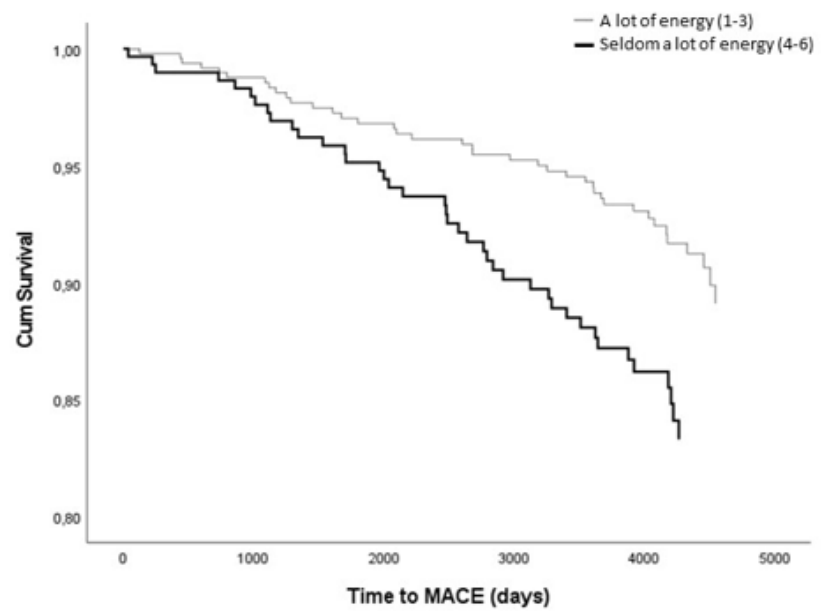

Figure 9. Cox regression analyses of event free survival in relation to the items "seldom feeling full of pep" (A) Hazard ratio 1.8, 95\% Confidence interval from 1.1 to $2.9, \mathrm{p}=\mathbf{0 . 0 1 3}$ and "seldom having a lot of energy" (B) Hazard ratio 1.8, 95\% Confidence interval from 1.2 to 2.9, $\mathrm{p}=\mathbf{0 . 0 0 9}$. The grey line represents answer options 1-3 (all of the time - most of the time - a good bit of the time) and the black line represents answer options 4-6 (some of the time - a little bit of the time - none of the time). Results are adjusted for sex, age, duration of diabetes, HbA1c, smoking status, SAD, ApoB/ApoA1, blood pressure and PWV. 
Multivariate Cox regression models including only independent vascular risk factors showed that "seldom feeling full of pep" (HR 1.2, 95\% CI: 1.1-1.4, p=0.006), "seldom having a lot of energy" (HR 1.3, 95\% CI: 1.1-1.5, p<0.001), "feeling worn out" (HR 1.2, 95\% CI: 1.0-1.4, $\mathrm{p}=0.020)$ and "seldom feeling happy" (HR 1.2, 95\% CI: 1.0-1.4, p=0.012) remained independent risk factors for MACE, as well as: male sex, duration of diabetes, HbA1c, PWV and SAD.

We analyzed each item in SF-36 separately for men and women with multivariate Cox regression models. For men, "seldom feeling full of pep" (HR: 1.2, 95\% CI: 1.0-1.4, $\mathrm{p}=0.015)$ and "seldom having a lot of energy" (HR: 1.3, 95\% CI: 1.1-1.5, p=0.003) were the only items from SF-36 that remained associated with MACE. In women, the same items, "seldom feeling full of pep" (HR: 1.4, 95\% CI: 1.0-1.9, p=0.030) and "seldom having a lot of energy" (HR: 1.5, 95\% CI: 1.1-2.0, p=0.011) were also associated with MACE, but in this group even "feeling worn out" (HR: 1.4, 95\% CI: 1.0-1.9, p=0.029) was associated with MACE. Beyond other significant variables, PWV was the only variable that remained consistently significant in all the models in both women and men. So although there were four items from SF-36 that remained independent strong predictors for MACE after adjustment for traditional risk factors and other more recent predictors such as $\mathrm{PWV}^{129}$ and $\mathrm{SAD}^{104}$, we selected the two questions about pep and energy as they had remained consistently significant in all our analyses for both men and women.

It is not new to say that patients with T2DM may have worse QoL and that a low QoL might be a risk factor for CVD in these patients ${ }^{86,87,135,136}$, but it is still not a routine practice to include QoL testing in the follow-up of patients with T2DM, which could be due to the lack of time in primary health care and the difficulty in choosing an appropriate measurement instrument ${ }^{137}$. Our results showed that single questions related to sense of vitality may serve as independent markers of the risk for MACE also when traditional risk factors and novel strong ones, such as PWV have been added to the equations. Hence it suggests the clinic utility of adding information on sense of stress when estimating the CVD risk in T2DM.

By adding these two questions: "During the last 4 weeks, did you feel full of pep?" and "During the last 4 weeks, did you have a lot of energy?" to the already well-established risk factors for CVD, it could be possible to enhance the traditional way of evaluating the risk of future vascular complications in these patients, making a more holistic assessment, but still in a simpler way than incorporating time-consuming, longer questionnaires. 


\section{STRENGTHS AND LIMITATIONS}

\section{Paper I}

We were able to show that after just 1 month of RT, many of the participants had their highest levels of RMR, suggesting a rapid effect of RT. I also consider a strength the fact that we used meals from well-known fast-food restaurants, as it makes these results more like real life outside of a traditional study population, which is positive from a clinical point of view.

I am aware of the limitation of having a population of healthy individuals, as it makes it more difficult to study some aspects such the potential anabolic effects of insulin, as this population does not have a known insulin resistance.

The fact that we only included men in this study may be seen as an important limitation too, but the reason why we chose this group was the fact that men increase their muscle volume as a response to RT about twice as much compared with women ${ }^{112}$, allowing for more reliable results in a shorter period of time.

Another reservation is the limited amount of training time and repetitions, as it related positively with the increase in RMR.

Further investigations with a mixed population of women and men, longer follow-up and also studies on patients with the criteria for metabolic syndrome are needed to obtain more reliable results.

\section{Paper II}

One of the main limitations of this study is the way the blueberries were ingested, as it seemed quite common to add sugar to the consuming of the berries, which could have influenced our results. However, our intention was to reproduce ordinary habits of berry consumption to make it easier to apply our results to everyday routines. 
The lack of control during the resting period could be a limitation, although the results of our analysis suggest good compliance.

The sample size was adjusted for possible losses, with some participants unable to complete the study period due to exercise-related injuries or weather conditions, but we are aware of the small sample size.

A strength of the study is the selected antioxidant source, as many studies have chosen treatment with different vitamins as antioxidants, with controversial outcomes ${ }^{74}$, while the use of blueberries has shown more favorable results ${ }^{78,138-140}$. There are indeed few studies that investigate the effect of blueberries in combination with exercise in humans, and I know of no other study with a similar design. Of particular interest is the possibility to take measurements in direct relation to running-races in each study period.

Further larger studies with cleaner ingestion of berries are needed to explore the effects of blueberries on CVD risk factors.

\section{Paper III}

The major strength of this study is the length of the running-races, as most of the studies relating exercise to risk factors for CVD are conducted with professional athletes and longdistance runners. We studied the effects of a $5 \mathrm{~km}$ run, which is a very extended distance for non-elite runners. This makes our results easier to extrapolate to a general population with common running habits.

A limitation of this study is the lack of more extensive examination of myocardial status in order to interpretate the clinical importance of troponin $\mathrm{T}$ release, such as echocardiography.

It would have been interesting to complement the samples with other hormones that influence glucose homeostasis, such as IGF-1, epinephrine and GH, to make a more accurate interpretation of our results.

Further studies with a wider population, including participants without previous running experience and also patients with the criteria for metabolic syndrome, are needed. 


\section{Paper IV}

The major strengths are the large population included, the long-term follow-up (11 years) that is still ongoing and gives the possibility of further analysis, the accessibility of the SF-36 questionnaire and the access to national health registers with high validity. An important aspect is also that the results were independent of well-studied risk markers for CVD such as PWV.

The major weakness is that only a selected part of the SF-36 was used. However, the objective of this study was to investigate whether selected single questions from SF-36 could be used as independent risk markers for MACE, simplifying the collection of information in clinical practice.

For further investigations, it could be useful to measure QoL over time to follow possible changes and their impact on the future risk of developing CVD. 


\section{SPECIFIC CONCLUSIONS AND FUTURE PERSPECTIVES}

\section{Paper I}

We conclude that it is achievable to increase RMR and muscle mass through only 3 months of regular RT, with this increase in RMR dependent on both an increase in muscle mass and a higher RMR per kg of fat-free mass.

The changes in RMR, muscle mass and strength were independent of the origin of extra protein intake, with equivalence between combining RT with whey protein powder intake or with an extra meal of fast-food containing a similar amount protein but an increased caloric intake. However, this general increase in caloric intake, seems to be unbeneficial regarding risk of CVD, as this group tended to gain more fat tissue and showed reduced insulin sensitivity and higher ApoB levels.

We suggest that regular resistance training maintained over time, and combined with extra protein intake, could be an additional strategy in the treatment of obesity due to an RMR increase.

\section{Paper II}

In the mixed population, including both consumers and non-consumers of blueberries, we found cardiovascular protective results after 4 weeks of regular exercise with ameliorated insulin sensitivity and a positive lipid profile. Even a single race of only $5 \mathrm{~km}$ had positive metabolic effects, comprising lower fasting glucose and triglycerides the morning after the race.

Our results suggest a possible anti-inflammatory effect of training when maintained over time. 
The presence of troponin $\mathrm{T}$ after a $5 \mathrm{~km}$ running-race in almost half of the races is a very interesting finding, because of its clinical importance when making a medical assessment evaluating chest pain.

Blueberries seem to have a favorable effect on the lipid profile and the berries attenuated the troponin $\mathrm{T}$ release after the races, suggesting cardioprotective effects. In contrast, we found higher fasting glucose levels, which could be secondary to concomitant food ingestion.

\section{Paper III}

Running a relative short distance of $5 \mathrm{~km}$, a distance common among recreational runners, may not be as advantageous as expected from a cardiovascular point of view, at least when running at maximal speed.

We observed a reduction in insulin sensitivity that was not fully compensated by parallel increased insulin levels not achieving normoglycemia, as well as elevated cortisol levels and troponin $\mathrm{T}$ release that was detected in most of the individuals after the race.

It is, however, not possible to evaluate the clinical importance of these observations in the long term based on our findings, although they are very interesting when making a medical assessment of patients with elevated troponin $\mathrm{T}$.

\section{Paper IV}

The results in this study suggest a novel approach to face the cardiovascular risk algorithm in patients with T2DM, adding a more holistic medical assessment that includes sense of stress and enabling simpler data collection regarding vitality in these patients.

The two single questions from the SF-36: "During the last 4 weeks, did you feel full of pep?" and "During the last 4 weeks, did you have a lot of energy?" might be added to the list of well-established independent risk factors for predicting MACE in patients with T2DM, opening up the possibility of applying earlier interventions to diminish the risk of developing cardiovascular complications in these patients. 


\section{GENERAL CONCLUSION}

Metabolic syndrome has been defined in different ways, but despite some variations, it is mainly defined as a pathologic condition characterized by abdominal obesity, insulin resistance, hypertension and hyperlipidemia ${ }^{141}$. Even if obesity not always implies T2DM; metabolic syndrome, T2DM and obesity are closely related.

There is a big need of diminish the impact of the metabolic syndrome all over the world as it has become a global epidemy that unfortunately is expected to continue increasing successively. Even if there is a genetical factor in some cases ${ }^{142}$, genetics is still a minor component, being lifestyle and diet the main causes behind metabolic syndrome and obesity. Last decade, several studies have found that epigenetic modifications in key tissues like adipose tissue, skeletal muscle, blood, liver, and pancreatic islets, may have an important role in the development of obesity and T2DM. Aging and genetic variation may affect epigenetic mechanism in patients with obesity and T2DM, but even lifestyle habits like physical activity and diet contribute to changes in the epigenome, even in the intrauterine environment ${ }^{143}$. This suggests that the lifestyle and diet habits of the parents, may influence the risk for developing metabolic related diseases in their offspring. This makes it even more important to find strategies to stop the development of this epidemy since there is no cure for T2DM, but it is still possible to prevent this condition in many cases.

The studies discussed in this thesis, suggest that non-pharmacological methods may affect metabolic variables.

Only 3 months of regularly RT in combination with extra protein supplementation led to an increased RMR, which can be positive in a metabolic context. Four weeks of regular endurance training resulted in ameliorated insulin sensitivity, improved lipid profile and a possible anti-inflammatory effect. One single race of $5 \mathrm{~km}$ could reduce insulin sensitivity and elevate cortisol levels in the following hours, which is not metabolic advantageous. Otherwise, these values seemed to normalize during the day, and we even found fasting glucose and triglyceride levels that were lowered the morning after the race. The finding of 
Troponin $\mathrm{T}$ release in most of the individuals after the races, might be related to myocardial injury, but we found a tendency to lower Troponin $\mathrm{T}$ release after a period of regular training in women, which could indicate that a better physical condition could protect against myocardial stress.

Diet interventions showed an impact in metabolic variables too, with an increased amount of fat tissue, reduced insulin sensitivity and higher ApoB levels in the participants who consumed an extra hypercaloric meal from a fast-food restaurant. The regular ingestion of blueberries seemed to have a cardioprotective effect in running participants, resulting in a diminution of Troponin $\mathrm{T}$ release after a race and an ameliorated lipid profile.

Self-perceived health in T2DM seemed to predict the incidence of CVD, and it would be interesting to know more about interventions intended to improve perceived health and their impact in cardiovascular health.

Other non-pharmacological interventions like exposing to cold regularly, might also have beneficial metabolic effects like loss of weight and improved lipid and glucose profile (own nonpublished data).

More non-pharmacological interventions focused on prevention of metabolic syndrome are needed to target the younger population before the complex metabolic syndrome gets stablished.

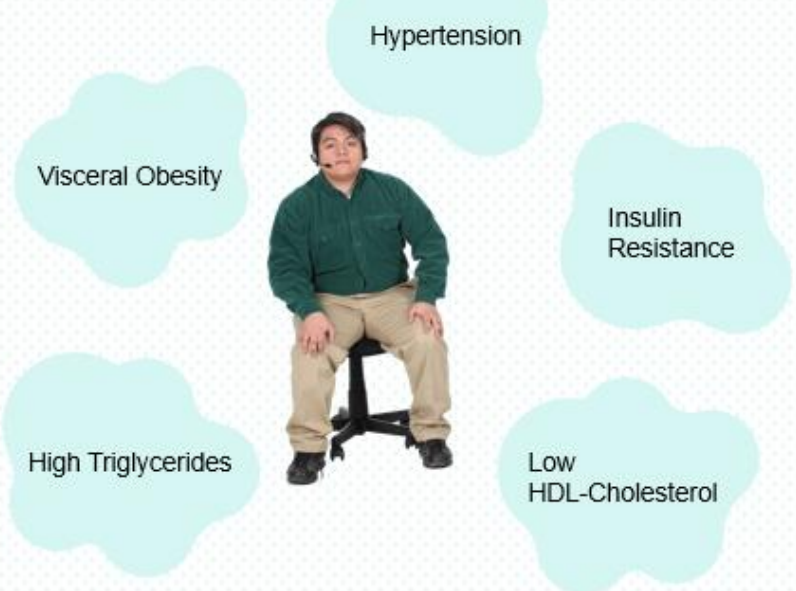

Metabolic syndrome 


\section{REFERENCES}

1. Eckel RH, Grundy SM, Zimmet PZ. The metabolic syndrome. Lancet. 2005;365(9468):14151428.

2. Flegal KM. Epidemiologic aspects of overweight and obesity in the United States. Physiology \& behavior. 2005;86(5):599-602.

3. Feingold K, Anawalt B, Boyce A, et al. Definitions, Classification, and Epidemiology of Obesity-Endotext. 2000.

4. Bays HE, Toth PP, Kris-Etherton PM, et al. Obesity, adiposity, and dyslipidemia: a consensus statement from the National Lipid Association. Journal of clinical lipidology. 2013;7(4):304383.

5. Grundy SM. Obesity, metabolic syndrome, and cardiovascular disease. The Journal of Clinical Endocrinology \& Metabolism. 2004;89(6):2595-2600.

6. Kyrou I, Randeva HS, Tsigos C, Kaltsas G, Weickert MO. Clinical problems caused by obesity. In: Endotext [Internet]. MDText. com, Inc.; 2018.

7. Mandviwala T, Khalid U, Deswal A. Obesity and cardiovascular disease: a risk factor or a risk marker? Current atherosclerosis reports. 2016;18(5):21.

8. Zalesin KC, Franklin BA, Miller WM, Peterson ED, McCullough PA. Impact of obesity on cardiovascular disease. Endocrinology and metabolism clinics of North America. 2008;37(3):663-684.

9. Dw H. James Wp. Obesity. Lancet. 2005;9492:1197-1209.

10. Erlingsson S, Herard S, Dahlqvist Leinhard O, et al. Men develop more intraabdominal obesity and signs of the metabolic syndrome after hyperalimentation than women. Metabolism. 2009;58(7):995-1001.

11. Claesson A-L, Holm G, Ernersson Å, Lindström T, Nystrom FH. Two weeks of overfeeding with candy, but not peanuts, increases insulin levels and body weight. Scandinavian journal of clinical and laboratory investigation. 2009;69(5):598-605.

12. West $D$, Gorin A, Subak $L$, et al. Program to Reduce Incontinence by Diet and Exercise (PRIDE) Research Group. A motivation-focused weight loss maintenance program is an effective alternative to a skill-based approach. Int J Obes (Lond). 2011;35(2):259-269.

13. Jeffery RW, Epstein LH, Wilson GT, Drewnowski A, Stunkard AJ, Wing RR. Long-term maintenance of weight loss: current status. Health psychology. 2000;19(1S):5.

14. Chamnan P, Simmons RK, Forouhi NG, et al. Incidence of type 2 diabetes using proposed $\mathrm{HbA1c}$ diagnostic criteria in the european prospective investigation of cancer-norfolk cohort: implications for preventive strategies. Diabetes Care. 2011;34(4):950-956.

15. Weir GC, Bonner-Weir S. Five Stages of Evolving Beta-Cell Dysfunction During Progression to Diabetes. Diabetes. 2004;53(suppl 3):S16-S21.

16. Harris MI, Klein R, Welborn TA, Knuiman MW. Onset of NIDDM occurs at least 4-7 yr before clinical diagnosis. Diabetes Care. 1992;15(7):815-819.

17. Fowler MJ. Microvascular and Macrovascular Complications of Diabetes. Clinical Diabetes. 2008;26(2):77-82.

18. Paterson AD, Rutledge BN, Cleary PA, Lachin JM, Crow RS. The effect of intensive diabetes treatment on resting heart rate in type 1 diabetes: the Diabetes Control and Complications 
Trial/Epidemiology of Diabetes Interventions and Complications study. Diabetes care. 2007;30(8):2107-2112.

19. Laing S, Swerdlow A, Slater S, et al. Mortality from heart disease in a cohort of 23,000 patients with insulin-treated diabetes. Diabetologia. 2003;46(6):760-765.

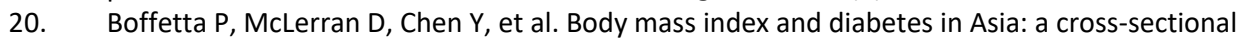
pooled analysis of 900,000 individuals in the Asia cohort consortium. PLoS One. 2011;6(6):e19930.

21. Willi C, Bodenmann P, Ghali WA, Faris PD, Cornuz J. Active smoking and the risk of type 2 diabetes: a systematic review and meta-analysis. Jama. 2007;298(22):2654-2664.

22. Hu FB, Manson JE, Stampfer MJ, et al. Diet, lifestyle, and the risk of type 2 diabetes mellitus in women. N Engl J Med. 2001;345(11):790-797.

23. Chen L, Magliano DJ, Zimmet PZ. The worldwide epidemiology of type 2 diabetes mellitus-present and future perspectives. Nat Rev Endocrinol. 2011;8(4):228-236.

24. Olokoba AB, Obateru OA, Olokoba LB. Type 2 diabetes mellitus: a review of current trends. Oman Med J. 2012;27(4):269-273.

25. Kashyap SR, Gatmaitan P, Brethauer S, Schauer P. Bariatric surgery for type 2 diabetes: weighing the impact for obese patients. Cleve Clin J Med. 2010;77(7):468-476.

26. Sjöström L, Peltonen M, Jacobson P, et al. Association of Bariatric Surgery With Long-term Remission of Type 2 Diabetes and With Microvascular and Macrovascular Complications. JAMA. 2014;311(22):2297-2304.

27. Poehlman ET. A review: exercise and its influence on resting energy metabolism in man. Med Sci Sports Exerc. 1989;21(5):515-525.

28. Blasco Redondo R. Resting energy expenditure; assessment methods and applications. Nutr Hosp. 2015;31 Suppl 3:245-254.

29. Buscemi S, Caimi G, Verga S. Resting metabolic rate and postabsorptive substrate oxidation in morbidly obese subjects before and after massive weight loss. Int J Obes Relat Metab Disord. 1996;20(1):41-46.

30. Valtueña S, Blanch S, Barenys M, Solà R, Salas-Salvadó J. Changes in body composition and resting energy expenditure after rapid weight loss: is there an energy-metabolism adaptation in obese patients? Int J Obes Relat Metab Disord. 1995;19(2):119-125.

31. Moreno $\mathrm{M}$, Lombardi $\mathrm{A}$, Beneduce $\mathrm{L}$, et al. Are the effects of $\mathrm{T} 3$ on resting metabolic rate in euthyroid rats entirely caused by T3 itself? Endocrinology. 2002;143(2):504-510.

32. Ravussin E. Low resting metabolic rate as a risk factor for weight gain: role of the sympathetic nervous system. Int J Obes Relat Metab Disord. 1995;19 Suppl 7:S8-S9.

33. Wilson M-MG, Morley JE. Invited review: aging and energy balance. Journal of Applied Physiology. 2003;95(4):1728-1736.

34. Johnstone AM, Murison SD, Duncan JS, Rance KA, Speakman JR. Factors influencing variation in basal metabolic rate include fat-free mass, fat mass, age, and circulating thyroxine but not sex, circulating leptin, or triiodothyronine. The American journal of clinical nutrition. 2005;82(5):941-948.

35. Ernersson $\AA$, Nystrom FH, Lindström T. Long-term increase of fat mass after a four week intervention with fast food based hyper-alimentation and limitation of physical activity. Nutrition \& Metabolism. 2010;7(1):68.

36. Himms-Hagen J. Role of thermogenesis in the regulation of energy balance in relation to obesity. Can J Physiol Pharmacol. 1989;67(4):394-401.

37. Cannon B, Nedergaard J. Brown adipose tissue: function and physiological significance. Physiological reviews. 2004;84(1):277-359.

38. Aldhahi W, Hamdy O. Adipokines, inflammation, and the endothelium in diabetes. Current diabetes reports. 2003;3(4):293-298.

39. Ronti T, Lupattelli G, Mannarino E. The endocrine function of adipose tissue: an update. Clinical endocrinology. 2006;64(4):355-365. 
40. Rosen ED, Spiegelman BM. Adipocytes as regulators of energy balance and glucose homeostasis. Nature. 2006;444(7121):847-853.

41. Ouellet V, Labbé SM, Blondin DP, et al. Brown adipose tissue oxidative metabolism contributes to energy expenditure during acute cold exposure in humans. The Journal of clinical investigation. 2012;122(2):545-552.

42. Romu T, Vavruch C, Dahlqvist-Leinhard O, et al. A randomized trial of cold-exposure on energy expenditure and supraclavicular brown adipose tissue volume in humans. Metabolism. 2016;65(6):926-934.

43. Berbée JF, Boon MR, Khedoe PPS, et al. Brown fat activation reduces hypercholesterolaemia and protects from atherosclerosis development. Nature communications. 2015;6(1):1-11.

44. Bartelt A, John C, Schaltenberg $\mathrm{N}$, et al. Thermogenic adipocytes promote HDL turnover and reverse cholesterol transport. Nat Commun. 2017;8:15010.

45. Hanssen MJ, Hoeks J, Brans B, et al. Short-term cold acclimation improves insulin sensitivity in patients with type 2 diabetes mellitus. Nat Med. 2015;21(8):863-865.

46. Weir G, Ramage LE, Akyol M, et al. Substantial Metabolic Activity of Human Brown Adipose Tissue during Warm Conditions and Cold-Induced Lipolysis of Local Triglycerides. Cell Metab. 2018;27(6):1348-1355.e1344.

47. Bryner RW, Ullrich IH, Sauers J, et al. Effects of Resistance vs. Aerobic Training Combined With an 800 Calorie Liquid Diet on Lean Body Mass and Resting Metabolic Rate. Journal of the American College of Nutrition. 1999;18(2):115-121.

48. Broeder CE, Burrhus KA, Svanevik LS, Wilmore JH. The effects of either high-intensity resistance or endurance training on resting metabolic rate. The American Journal of Clinical Nutrition. 1992;55(4):802-810.

49. Stiegler $P$, Cunliffe $A$. The role of diet and exercise for the maintenance of fat-free mass and resting metabolic rate during weight loss. Sports medicine. 2006;36(3):239-262.

50. Dolezal BA, Potteiger JA. Concurrent resistance and endurance training influence basal metabolic rate in nondieting individuals. Journal of Applied Physiology. 1998;85(2):695-700.

51. Pratley $R$, Nicklas B, Rubin M, et al. Strength training increases resting metabolic rate and norepinephrine levels in healthy 50- to 65-yr-old men. Journal of Applied Physiology. $1994 ; 76(1): 133-137$.

52. Lemmer Jt, Ivey FM, Ryan AS, et al. Effect of strength training on resting metabolic rate and physical activity: age and gender comparisons. Medicine \& Science in Sports \& Exercise. 2001;33(4):532-541.

53. Taaffe DR, Pruitt L, Reim J, Butterfield G, Marcus R. Effect of Sustained Resistance Training on Basal Metabolic Rate in Older Women. Journal of the American Geriatrics Society. 1995;43(5):465-471.

54. Fryburg DA, Jahn LA, Hill SA, Oliveras DM, Barrett EJ. Insulin and insulin-like growth factor-I enhance human skeletal muscle protein anabolism during hyperaminoacidemia by different mechanisms. The Journal of clinical investigation. 1995;96(4):1722-1729.

55. Orchard TJ, Temprosa M, Goldberg R, et al. The Effect of Metformin and Intensive Lifestyle Intervention on the Metabolic Syndrome: The Diabetes Prevention Program Randomized Trial. Annals of Internal Medicine. 2005;142(8):611-619.

56. Knowler WC, Barrett-Connor E, Fowler SE, et al. Reduction in the incidence of type 2 diabetes with lifestyle intervention or metformin. The New England journal of medicine. 2002;346(6):393-403.

57. Chudyk A, Petrella RJ. Effects of Exercise on Cardiovascular Risk Factors in Type 2 Diabetes. A meta-analysis. 2011;34(5):1228-1237.

58. O'Gorman DJ, Krook A. Exercise and the Treatment of Diabetes and Obesity. Medical Clinics of North America. 2011;95(5):953-969.

59. Saravia SGM, Knebel F, Schroeckh S, et al. Cardiac troponin T release and inflammation demonstrated in marathon runners. Clin Lab. 2010;56(1-2):51-58. 
60. Goussetis E, Spiropoulos A, Tsironi M, et al. Spartathlon, a 246 kilometer foot race: effects of acute inflammation induced by prolonged exercise on circulating progenitor reparative cells. Blood Cells, Molecules, and Diseases. 2009;42(3):294-299.

61. Neubauer O, König D, Wagner K-H. Recovery after an Ironman triathlon: sustained inflammatory responses and muscular stress. European journal of applied physiology. 2008;104(3):417-426.

62. Nakajima K, Kusuhara M, Yonemura A, et al. Increasing physical fitness does not proportionally decrease circulating $C$-reactive protein level in men with varying fitness. Metabolism. 2008;57(5):650-657.

63. Margeli A, Skenderi K, Tsironi M, et al. Dramatic elevations of interleukin- 6 and acute-phase reactants in athletes participating in the ultradistance foot race spartathlon: severe systemic inflammation and lipid and lipoprotein changes in protracted exercise. The Journal of Clinical Endocrinology \& Metabolism. 2005;90(7):3914-3918.

64. Mattusch F, Dufaux B, Heine O, Mertens I, Rost R. Reduction of the plasma concentration of $\mathrm{C}$-reactive protein following nine months of endurance training. International journal of sports medicine. 2000;21(01):21-24.

65. Mingels AM, Jacobs LH, Kleijnen VW, et al. Cardiac troponin T elevations, using highly sensitive assay, in recreational running depend on running distance. Clinical research in cardiology. 2010;99(6):385-391.

66. Fu F, Nie J, Tong T. Serum cardiac troponin T in adolescent runners: effects of exercise intensity and duration. International journal of sports medicine. 2009;30(03):168-172.

67. De Lemos JA, Drazner MH, Omland T, et al. Association of troponin T detected with a highly sensitive assay and cardiac structure and mortality risk in the general population. Jama. 2010;304(22):2503-2512.

68. VanBruggen MD, Hackney AC, McMurray RG, Ondrak KS. The relationship between serum and salivary cortisol levels in response to different intensities of exercise. International Journal of sports physiology and performance. 2011;6(3):396-407.

69. Whitworth JA, Williamson PM, Mangos G, Kelly JJ. Cardiovascular consequences of cortisol excess. Vasc Health Risk Manag. 2005;1(4):291-299.

70. Borghouts L, Keizer H. Exercise and insulin sensitivity: a review. International journal of sports medicine. 2000;21(01):1-12.

71. Nystrom FH, Quon MJ. Insulin signalling: metabolic pathways and mechanisms for specificity. Cellular signalling. 1999;11(8):563-574.

72. Halliwell B. Antioxidants in Human Health and Disease. Annual Review of Nutrition. 1996;16(1):33-50.

73. Velicer $\mathrm{CM}$, Ulrich $\mathrm{CM}$. Vitamin and mineral supplement use among US adults after cancer diagnosis: a systematic review. Journal of Clinical Oncology. 2008;26(4):665-673.

74. Bjelakovic G, Nikolova D, Gluud LL, Simonetti RG, Gluud C. Mortality in randomized trials of antioxidant supplements for primary and secondary prevention: systematic review and metaanalysis. Jama. 2007;297(8):842-857.

75. Spencer EH, Bendich A, Frank E. Vitamin and mineral supplement use among US medical students: A longitudinal study. Journal of the American Dietetic Association.

2006;106(12):1975-1983.

76. Nichter M, Thompson JJ. For my wellness, not just my illness: North Americans' use of dietary supplements. Culture, medicine and psychiatry. 2006;30(2):175-222.

77. Lyons MM, Yu C, Toma R, et al. Resveratrol in raw and baked blueberries and bilberries. Journal of Agricultural and Food Chemistry. 2003;51(20):5867-5870.

78. Erlund I, Koli R, Alfthan $\mathrm{G}$, et al. Favorable effects of berry consumption on platelet function, blood pressure, and HDL cholesterol. The American journal of clinical nutrition. 2008;87(2):323-331.

79. World Health Osrganization (WHO). WHOQOL: Measuring Quality of Life. https://www.who.int/tools/whogol. Published 2012, March 1. Accessed. 
80. Theofilou P. Quality of Life: Definition and Measurement. Europe's journal of psychology. 2013;9(1).

81. Karimi M, Brazier J. Health, Health-Related Quality of Life, and Quality of Life: What is the Difference? PharmacoEconomics. 2016;34(7):645-649.

82. Rosengren A, Hawken S, Ôunpuu S, et al. Association of psychosocial risk factors with risk of acute myocardial infarction in 11119 cases and 13648 controls from 52 countries (the INTERHEART study): case-control study. The Lancet. 2004;364(9438):953-962.

83. Barefoot JC, Schroll M. Symptoms of depression, acute myocardial infarction, and total mortality in a community sample. Circulation. 1996;93(11):1976-1980.

84. McEwen LN, Kim C, Haan MN, et al. Are health-related quality-of-life and self-rated health associated with mortality? Insights from Translating Research Into Action for Diabetes (TRIAD). Primary Care Diabetes. 2009;3(1):37-42.

85. Kamarul Imran M, Ismail AA, Naing L, Wan Mohamad WB. Type 2 diabetes mellitus patients with poor glycaemic control have lower quality of life scores as measured by the Short Form36. Singapore Med J. 2010;51(2):157-162.

86. Pinheiro LC, Reshetnyak E, Sterling MR, Richman JS, Kern LM, Safford MM. Using healthrelated quality of life to predict cardiovascular disease events. Quality of Life Research. 2019;28(6):1465-1475.

87. Hayes AJ, Clarke PM, Glasziou PG, Simes RJ, Drury PL, Keech AC. Can Self-Rated Health Scores Be Used for Risk Prediction in Patients With Type 2 Diabetes? Diabetes Care. 2008;31(4):795797.

88. Briggs AH, Bhatt DL, Scirica BM, et al. Health-related quality-of-life implications of cardiovascular events in individuals with type 2 diabetes mellitus: A subanalysis from the Saxagliptin Assessment of Vascular Outcomes Recorded in Patients with Diabetes Mellitus (SAVOR)-TIMI 53 trial. Diabetes Res Clin Pract. 2017;130:24-33.

89. Coons SJ, Rao S, Keininger DL, Hays RD. A comparative review of generic quality-of-life instruments. Pharmacoeconomics. 2000;17(1):13-35.

90. Brazier JE, Harper R, Jones NM, et al. Validating the SF-36 health survey questionnaire: new outcome measure for primary care. Bmj. 1992;305(6846):160-164.

91. McHorney CA, Ware JE, Lu JFR, Sherbourne CD. The MOS 36-Item Short-Form Health Survey (SF-36): III. Tests of Data Quality, Scaling Assumptions, and Reliability across Diverse Patient Groups. Medical Care. 1994;32(1):40-66.

92. Persson L-O, Karlsson J, Bengtsson C, Steen B, Sullivan M. The Swedish SF-36 Health Survey II. Evaluation of clinical validity: results from population studies of elderly and women in Gothenborg. Journal of clinical epidemiology. 1998;51(11):1095-1103.

93. Sullivan M, Karlsson J. The Swedish SF-36 Health Survey III. Evaluation of criterion-based validity: results from normative population. Journal of clinical epidemiology. 1998;51(11):1105-1113.

94. Sullivan M, Karlsson J, Ware JE. The Swedish SF-36 Health Survey-I. Evaluation of data quality, scaling assumptions, reliability and construct validity across general populations in Sweden. Social Science \& Medicine. 1995;41(10):1349-1358.

95. Ware JE, Jr., Sherbourne CD. The MOS 36-item short-form health survey (SF-36). I. Conceptual framework and item selection. Med Care. 1992;30(6):473-483.

96. Vavruch C, Lanne T, Fredrikson M, Lindstrom T, Ostgren CJ, Nystrom FH. Serum leptin levels are independently related to the incidence of ischemic heart disease in a prospective study of patients with type 2 diabetes. Cardiovasc Diabetol. 2015;14:62.

97. Sun Q, van Dam RM, Spiegelman D, Heymsfield SB, Willett WC, Hu FB. Comparison of DualEnergy X-Ray Absorptiometric and Anthropometric Measures of Adiposity in Relation to Adiposity-Related Biologic Factors. American Journal of Epidemiology. 2010;172(12):14421454.

98. Haarbo J, Gotfredsen A, Hassager C, Christiansen C. Validation of body composition by dual energy X-ray absorptiometry (DEXA). Clinical Physiology. 1991;11(4):331-341. 
99. Ballard TP, Fafara L, Vukovich MD. Comparison of Bod Pod ${ }^{\circledR}$ and DXA in female collegiate athletes. Medicine and science in sports and exercise. 2004;36(4):731-735.

100. Wallhuss A, Isik M, Nystrom FH. Comparison of the subjective sense of high or low metabolism and objectively measured resting metabolic rate. Scandinavian journal of clinical and laboratory investigation. 2010;70(5):334-337.

101. Bonora $\mathrm{E}$, Targher $\mathrm{G}$, Alberiche $\mathrm{M}$, et al. Homeostasis model assessment closely mirrors the glucose clamp technique in the assessment of insulin sensitivity: studies in subjects with various degrees of glucose tolerance and insulin sensitivity. Diabetes care. 2000;23(1):57-63.

102. Katz A, Nambi SS, Mather K, et al. Quantitative insulin sensitivity check index: a simple, accurate method for assessing insulin sensitivity in humans. The Journal of Clinical Endocrinology \& Metabolism. 2000;85(7):2402-2410.

103. Aardal E, Holm A-C. Cortisol in saliva-reference ranges and relation to cortisol in serum. 1995

104. Dahlen EM, Bjarnegard N, Lanne T, Nystrom FH, Ostgren CJ. Sagittal abdominal diameter is a more independent measure compared with waist circumference to predict arterial stiffness in subjects with type 2 diabetes--a prospective observational cohort study. Cardiovasc Diabetol. 2013;12:55.

105. Jennersjo P, Ludvigsson J, Lanne T, Nystrom FH, Ernerudh J, Ostgren CJ. Pedometerdetermined physical activity is linked to low systemic inflammation and low arterial stiffness in Type 2 diabetes. Diabet Med. 2012;29(9):1119-1125.

106. Wijkman M, Lanne T, Engvall J, Lindstrom T, Ostgren CJ, Nystrom FH. Masked nocturnal hypertension--a novel marker of risk in type 2 diabetes. Diabetologia. 2009;52(7):1258-1264.

107. Laurent S, Cockcroft J, Van Bortel L, et al. Expert consensus document on arterial stiffness: methodological issues and clinical applications. European Heart Journal. 2006;27(21):25882605.

108. Kirschbaum C, Pirke KM, Hellhammer DH. The 'Trier Social Stress Test' - A Tool for Investigating Psychobiological Stress Responses in a Laboratory Setting. Neuropsychobiology. 1993;28(1-2):76-81.

109. Ristow M, Zarse K, Oberbach A, et al. Antioxidants prevent health-promoting effects of physical exercise in humans. Proceedings of the National Academy of Sciences. 2009;106(21):8665-8670.

110. Wolfe RR. Effects of insulin on muscle tissue. Current Opinion in Clinical Nutrition \& Metabolic Care. 2000;3(1):67-71.

111. Jørgensen JOL, Vahl N, Dall R, Christiansen JS. Resting metabolic rate in healthy adults: Relation to growth hormone status and leptin levels. Metabolism. 1998;47(9):1134-1139.

112. Ivey FM, Roth SM, Ferrell RE, et al. Effects of Age, Gender, and Myostatin Genotype on the Hypertrophic Response to Heavy Resistance Strength Training. The Journals of Gerontology: Series A. 2000;55(11):M641-M648.

113. James DE, Kraegen EW, Chisholm DJ. Effect of exercise training on whole-body insulin sensitivity and responsiveness. Journal of Applied Physiology. 1984;56(5):1217-1222.

114. Duttaroy S, Thorell D, Karlsson L, Börjesson M. A single-bout of one-hour spinning exercise increases troponin T in healthy subjects. Scandinavian Cardiovascular Journal. 2012;46(1):26.

115. Kurth-Kraczek EJ, Hirshman MF, Goodyear LJ, Winder WW. 5' AMP-activated protein kinase activation causes GLUT4 translocation in skeletal muscle. Diabetes. 1999;48(8):1667-1671.

116. Barth E, Albuszies G, Baumgart K, et al. Glucose metabolism and catecholamines. Critical Care Medicine. 2007;35(9):S508-S518.

117. Schwarz L, Kindermann W. $\beta$-Endorphin, adrenocorticotropic hormone, cortisol and catecholamines during aerobic and anaerobic exercise. European Journal of Applied Physiology and Occupational Physiology. 1990;61(3):165-171.

118. Wideman L, Weltman JY, Hartman ML, Veldhuis JD, Weltman A. Growth hormone release during acute and chronic aerobic and resistance exercise: recent findings. Sports Med. 2002;32(15):987-1004. 
119. Clemmons DR. Involvement of insulin-like growth factor-I in the control of glucose homeostasis. Current Opinion in Pharmacology. 2006;6(6):620-625.

120. LeRoith D, Yakar S. Mechanisms of Disease: metabolic effects of growth hormone and insulin-like growth factor 1. Nature Clinical Practice Endocrinology \& Metabolism. 2007;3(3):302-310.

121. Christiansen JJ, Djurhuus CB, Gravholt $\mathrm{CH}$, et al. Effects of cortisol on carbohydrate, lipid, and protein metabolism: studies of acute cortisol withdrawal in adrenocortical failure. The Journal of Clinical Endocrinology \& Metabolism. 2007;92(9):3553-3559.

122. Brillon D, Zheng B, Campbell R, Matthews D. Effect of cortisol on energy expenditure and amino acid metabolism in humans. American Journal of Physiology-Endocrinology And Metabolism. 1995;268(3):E501-E513.

123. Vilela E, Bastos J, Rodrigues R, Nunes J. High-sensitivity troponin after running--a systematic review. Neth J Med. 2014;72(1):5-9.

124. Shave R, George KP, Atkinson G, et al. Exercise-induced cardiac troponin T release: a metaanalysis. Medicine and science in sports and exercise. 2007;39(12):2099-2106.

125. Andersen K, Farahmand B, Ahlbom A, et al. Risk of arrhythmias in 52755 long-distance crosscountry skiers: a cohort study. European heart journal. 2013;34(47):3624-3631.

126. Rådholm K, Tengblad A, Dahlén $E$, et al. The impact of using sagittal abdominal diameter to predict major cardiovascular events in European patients with type 2 diabetes. Nutr Metab Cardiovasc Dis. 2017;27(5):418-422.

127. Dahlen EM, Tengblad A, Lanne T, et al. Abdominal obesity and low-grade systemic inflammation as markers of subclinical organ damage in type 2 diabetes. Diabetes Metab. 2014;40(1):76-81.

128. Dahlén EM, Länne T, Engvall J, et al. Carotid intima-media thickness and apolipoprotein B/apolipoprotein A-I ratio in middle-aged patients with Type 2 diabetes. Diabetic Medicine. 2009;26(4):384-390.

129. Wijkman M, Länne T, Östgren CJ, Nystrom FH. Aortic pulse wave velocity predicts incident cardiovascular events in patients with type 2 diabetes treated in primary care. Journal of Diabetes and its Complications. 2016;30(7):1223-1228.

130. Wijkman M, Lanne T, Grodzinsky E, Ostgren CJ, Engvall J, Nystrom FH. Ambulatory systolic blood pressure predicts left ventricular mass in type 2 diabetes, independent of central systolic blood pressure. Blood Press Monit. 2012;17(4):139-144.

131. Jennersjö $P E$, Wijkman $M$, Wiréhn $A B$, et al. Circadian blood pressure variation in patients with type 2 diabetes--relationship to macro- and microvascular subclinical organ damage. Prim Care Diabetes. 2011;5(3):167-173.

132. Chisalita SI, Wijkman M, Davidson LT, Spångeus A, Nyström F, Östgren CJ. Toe brachial index predicts major acute cardiovascular events in patients with type 2 diabetes independently of arterial stiffness. Diabetes Res Clin Pract. 2020;161:108040.

133. Johansson MA, Vavruch C, Östgren CJ, Nystrom FH. Circulating TNFrll levels predict incidence of ischemic heart disease and total mortality, independently of intima media thickness and pulse wave velocity in male with type 2 diabetes. Heart Vessels. 2021;36(10):1591-1596.

134. Jennersjo P, Guldbrand H, Bjorne S, et al. A prospective observational study of all-cause mortality in relation to serum 25-OH vitamin D3 and parathyroid hormone levels in patients with type 2 diabetes. Diabetol Metab Syndr. 2015;7:53.

135. Schram MT, Baan CA, Pouwer F. Depression and quality of life in patients with diabetes: a systematic review from the European depression in diabetes (EDID) research consortium. Current diabetes reviews. 2009;5(2):112-119.

136. Trikkalinou A, Papazafiropoulou AK, Melidonis A. Type 2 diabetes and quality of life. World journal of diabetes. 2017;8(4):120.

137. Jacobs JE. Quality of life: what does it mean for general practice? The British journal of general practice : the journal of the Royal College of General Practitioners. 2009;59(568):807808. 
138. Basu A, Rhone M, Lyons TJ. Berries: emerging impact on cardiovascular health. Nutrition Reviews. 2010;68(3):168-177.

139. Shukitt-Hale B. Blueberries and neuronal aging. Gerontology. 2012;58(6):518-523.

140. Kay CD, Holub BJ. The effect of wild blueberry (Vaccinium angustifolium) consumption on postprandial serum antioxidant status in human subjects. British Journal of Nutrition. 2002;88(4):389-397.

141. Saklayen MG. The Global Epidemic of the Metabolic Syndrome. Curr Hypertens Rep. 2018;20(2):12-12.

142. Locke AE, Kahali B, Berndt $\mathrm{SI}$, et al. Genetic studies of body mass index yield new insights for obesity biology. Nature. 2015;518(7538):197-206.

143. Ling C, Rönn T. Epigenetics in Human Obesity and Type 2 Diabetes. Cell Metabolism. 2019;29(5):1028-1044. 


\section{ACKNOWLEDGEMENTS}

Jag vill tacka dessa följande personer som på ett eller annat sätt har bidragit till att mitt arbete blev klart och gjorde resan roligare och mer intressant längs vägen.

Quiero dar las gracias a las siguientes personas, que de una manera $\mathrm{u}$ otra, han contribuido a que haya podido realizar mi trabajo y han hecho que el viaje fuera más interesante y divertido a lo largo del camino.

Torbjörn Lindström, min handledare. För att du alltid var där och stöttade mig både i mitt klinisk och forskningsarbete på ett väldigt ödmjukt och tålmodigt sätt. För ditt goda hjärta och din nyfikenhet. Jag saknar dig.

Fredrik Nyström, min handledare. För din entusiasm, ditt skarpa intellekt, ditt stöd under hela min resa som doktorand och inte minst för alla roliga historier som du har delat med dig. Du är en inspirationskälla och jag slutar aldrig förvånats av alla dina sidor.

Carl-Johan Östgren, för att du inte tvekade att hoppa in mitt i min doktorandutbildning när det behövdes och stöttade mig vid fortsatt arbetet.

Hanna Israelsson Larsen, för din handledning och ditt engagemang vid mitt sista arbete.

Alla andra författare och deltagare $i$ studierna, för att utan er hade det här arbetet aldrig varit möjligt.

Mina kollegor från endokrinkliniken, för att ni aldrig ger upp, för alla intressanta diskussioner och allt jag har lärt mig under våra år tillsammans.

Katarina Nägga, Monika Söderholm och Henrik Hugo, mina chefer senaste åren, för att ni stöttade mig i mitt forskningsarbete och gav mig möjligheten att jobba med det.

Mina kollegor på GAVA, för att ni har välkomnat mig med öppna armar och guidar mig i en ny värld.

Gizeh Pérez och Rosaura Casas, kvinnliga förebilder i forskningsvärlden, för att ni är så äkta och för att ni är mina vänner. Mujeres que inspiran!

Anna Spångeus, min vän och kollega, för alla våra timmar av brainstorming för att förändra världen och alla skratt och tokigheter som vände på de tuffare dagarna.

Lena Fröberg, min vän, för din hjälp som språkgranskare, ditt sinne för humör och vänskap.

Telle Lilja, vår supernanny, för att du berikar våra barns liv och hjälper oss att få vardagspusslet att gå ihop. 
Albano, el primo, por nuestras charlas interminables y ese lazo de sangre inventado.

Fanfou y Jean-Luc, porque las puertas de vuestro oasis de paz en La Renaudie siempre están abiertas para nuestra familia y por todos los buenos momentos que hemos pasado juntos.

Kerstin, Iris, Olle, Magnus, Lena, Lisa, Horiye, Johan N, Tillman, Johan A och Natalija, mina vänner, för alla glada skratt, härliga middagar och ovillkorlig vänskap.

Carolina, Carol, Mónica y Olivia, mis amigas de toda la vida, mujeres fantásticas. Porque ni el tiempo ni la distancia podrán separarnos nunca.

Christiane y Jesús, mis suegros, porque me recibisteis como una hija en vuestro hogar y por compartir conmigo todas esas comidas exquisitas y esos suculentos vinos.

Ana y Fermín, mis padres, porque siempre creísteis en mí y me disteis el apoyo y la posibilidad de cumplir mis sueños. A mamá, porque de ti aprendí a enfrentarme a la vida con una sonrisa y a no rendirme nunca, y a papá porque me has enseñado a valerme de la creatividad y la pasión por la música para enriquecer mis días y dar luz a los momentos oscuros.

Ainhoa, min stora kärlek, för att du alltid tror på mig och står ut med mina galna idéer, för att våra långa samtal aldrig tar slut, för att världen stannar när du kramar mig och för alla äventyr som vi har levt under alla våra år tillsammans, jag älskar dig.

Inés och Alba, mina underbara döttrar, för att ni lär mig så mycket varje dag, för att jag får följa med till era fantasivärldar, för att ni fyller mitt hjärta med värme och glädje och för att ni är de finaste, starkaste och roligaste småvarelser jag någonsin har mött. Os quiero hasta el infinito y más allá. 


\section{Papers}

The papers associated with this thesis have been removed for copyright reasons. For more details about these see:

http://urn.kb.se/resolve?urn=urn:nbn:se:liu:diva-179378 


\section{FACULTY OF MEDICIN AND HEALTH SCIENCES}

Linköping University Medical Dissertation No. 1781, 2021

Department of Health, Medicine and Caring Sciences

Linköping University

SE-581 83 Linköping, Sweden

www.liu.se 